\title{
Compliance with legal minimum wages and overtime pay regulations in China
}

\author{
Linxiang Ye ${ }^{1}, \mathrm{TH}$ Gindling ${ }^{2,3^{*}}$ and Shi Li ${ }^{2,4}$
}

\author{
* Correspondence: \\ gindling@umbc.edu \\ ${ }^{2}$ IZA, Bonn, Germany \\ ${ }^{3}$ Department of Economics, UMBC, \\ 1000 Hilltop Circle, Baltimore, MD, \\ USA \\ Full list of author information is \\ available at the end of the article
}

\begin{abstract}
We use a matched firm-employee data set to examine the extent of compliance with minimum wage and overtime pay regulations in Chinese formal sector firms. We find evidence that there is broad compliance with legal minimum wages in China; fewer than 3.5\% of full-time workers earn less than the legal monthly minimum wage. On the other hand, we find evidence that there is substantial non-compliance with overtime pay regulations; almost $29 \%$ of the employees who work overtime are not paid any additional wage for overtime hours, and 70\% are paid less than the legally-required 1.5 times the regular wage.

JEL codes: J3, J8, 017

Keywords: China; Labor protection regulations; Minimum wages; Overtime pay; Compliance
\end{abstract}


paid for overtime work, they are often paid less than the legally-mandated 1.5 times the regular wage. Over $40 \%$ of the employees who work overtime are paid less than 1.5 times the minimum wage for overtime work, and $70 \%$ are paid less than 1.5 times their regular wage for overtime work.

Minimum wages in China are set at the local government level, and there are dozens of different minimum wages across the country. Ours is the first study of minimum wages in China to use details of the earnings that firms report being paid to individual workers to estimate which workers are paid at or below the specific local minimum wage that applies to that worker and firm; other studies use either aggregated provincelevel data or worker's self-reported earnings from household surveys. These detailed earnings data allow us to get a more precise estimate of the relationship between the minimum wage and different components of the wage paid to workers in China.

Most of the empirical studies of the impact of recent minimum wage changes in China have focused on the potentially negative impact on employment. The results of these studies have been mixed, and where negative employment effects have been detected they are small. Our paper suggests two reasons why minimum wages seem to have a small impact in China even though there is broad compliance with minimum wage laws. First, we find that the market wage of the vast majority of full-time workers in China is above the monthly minimum wage. Second, our results suggest that when minimum wages are binding employers respond to an increase in minimum wages by increasing hours worked rather than reducing the number of workers they employ. Because non-compliance with overtime pay regulations is widespread, increasing working hours does not necessarily increase labor costs to employers.

We find that the relationship between minimum wages and the wages paid to workers depends on what "wage" is considered. Workers in formal sector firms in China are paid a "basic wage" plus supplements for transportation, risk, etc., plus a bonus related to productivity. All workers with the same position in the same firm (who do the same job) receive the same basic wage, which is determined prior to performing the work. Wage supplements, some legally-mandated and some at the discretion of the employer, are also determined before performing the work. Bonuses, on the other hand, depend on performance, may differ between workers in the same position in the firm, and are not determined until after the work is performed. Minimum wages appear to be taken into consideration by many firms when setting the basic wage. We find that basic wages are set at exactly the minimum wage for a relatively large fraction of workers. However, once bonuses and supplements are taken into account, almost all full-time workers earn more than the monthly minimum wage. We also find that there is a positive correlation across regions in China between the minimum wage and the basic wage. On the other hand, we find that there is a negative correlation between the minimum wage and the bonus. For most workers, the higher basic wage and lower bonus cancel each other out and the minimum wage is not significantly correlated with the total full-time wage. Only for workers in the most labor-intensive firms are higher minimum wages significantly correlated with higher total full-time wages. The firms where workers are most likely to be affected by legal minimum wages are disproportionately export-oriented firms with owners from Hong Kong, Taiwan or Macao and which are located in the more developed eastern Chinese provinces such as Guangdong. 


\section{Legal minimum wages, overtime pay regulations and mandatory wage supplements in China}

Prior to 1994, China had no minimum wage regulations. In 1993, the first regulations on minimum wages were issued by the Labor Ministry of China (the "Enterprise Minimum Wage Regulations"). In July 1994, a minimum wage was written into China's new version of the Labor Law. Clause 48 of that law states that all types of enterprises in China should comply with paying local minimum wages.

In 2004, the Enterprises Minimum Wage Regulations were replaced by more general Minimum Wages Regulations issued by the Department of Labor and Social Security. In these regulations the adjustment frequency of minimum wages was set to be at least once every two years and coverage was extended to town-village enterprises, to employees in micro-enterprises, and to part-time workers. Penalties for violations were increased substantially from an earlier range of $20-100 \%$ of the wage that was owed to a new range of $100-500 \%$ of the wage that was owed. Restrictions were also placed on what employers could include as part of the wage when comparing to the minimum wage (Wang and Gunderson, 2012). In determining if the wage is above the legal minimum, employers must not include overtime pay and legally-mandated supplements to the wage such as those for night shifts and dangerous environmental conditions such as high temperature, low temperature, underground working conditions and working in poisonous or noxious conditions. ${ }^{1}$

There is no unified minimum wage level for the entire nation. Instead, the task of setting minimum wages is delegated to the local governments. Clause 48 of the 1994 labor law requires that local governments set the minimum wage according to five principles: local minimum living expenses; the average wage level; local productivity; unemployment; and local economic development. In practice, each province-level government determines several possible minimum wage levels that could be adopted by local governments, generally three to five levels, according to local economic conditions and living standards. Then each prefectural city-level government within the province-level administrative area chooses the appropriate minimum wage levels from this published list, also based on local economic conditions and living standards. The law provides considerable flexibility for provinces and prefectural cities in setting their minimum wages. Typically, urban and suburban counties within a prefectural city have different minimum wage levels. ${ }^{2}$ Consequently, not only each province-level administrative area, but also each prefectural city-level administrative area, may have multiple county-level minimum wages. In 2009, the year covered by our data, over 41 different minimum wages were set in 31 different localities. ${ }^{3}$

The monthly minimum wage is based on a $40 \mathrm{~h}$ work week. According to labor regulations passed in 1994, laborers shall work no more than $8 \mathrm{~h}$ per day, 5 days per week. After consultation with trade unions and workers, a firm can extend the work day. If workers work more than the legal maximum of $40 \mathrm{~h}$ per week, they must be paid at least $150 \%$ of the wage they receive for regular hours, at least $200 \%$ of the regular wage if the overtime is on a "day of rest" (weekend), and at least 300\% the regular wage if the overtime is on a statutory holiday. Fines for violating overtime pay regulations include back pay plus an additional $50-100 \%$ of the wage owed.

The main mechanism for enforcing minimum wage and overtime regulations is inspections by the government labor authorities. If a violation is found during an 
inspection, then by law the first response of the labor inspectors is to issue a warning and require the firm to correct the violation (i.e., pay back pay owed to the worker). ${ }^{4}$ If firms correct the violation, no further action is taken. ${ }^{5}$ If firms do not correct the violation within a specified time, a fine may be imposed. If the firm neither corrects the violation nor pays the fine, then the case may be referred to the judicial authorities. In practice, almost all firms found to be in violation of minimum wage or overtime pay regulations correct the violation after a warning; very few firms are required to pay fines and almost none are referred to the judicial authorities. ${ }^{6}$

Labor enforcement efforts are concentrated in the period around the Chinese New Year and explicitly focus on firms that employ a large proportion of rural migrants. Many workers in manufacturing firms in China are rural migrants who leave the cities for home during the New Year's holiday and then return to the cities when the holidays are over. Inspections are concentrated in this period because bonuses, which can be a significant fraction of total pay, are paid to workers at the end of the year (before the holiday) and because worker contracts are most likely to be negotiated around this time. In the current year the inspection period was from November 24, 2014 to February 10, 2015 (New Year is February 19, 2015) and was conducted in three stages. In the first stage (November 24 to December 5) labor authorities mounted a publicity campaign to remind workers and firms of the legal rights of workers. In the second stage (December 6 to February 5) firms with a high proportion of rural migrant employees were inspected and, where necessary, ordered to make corrections. In the third stage, from February 6 to February 10, the inspections and their results are reviewed. Very few firms are inspected at any other time of year. In practice, inspections outside of the New Year period or in firms that do not employ a high fraction of rural immigrants occur only if a complaint is filed by workers. ${ }^{7}$

The Labor Law of the Chinese Peoples Republic usually includes minimum wages, overtime pay and contract violations of pay in the same clauses. ${ }^{8}$ Consistent with this, the labor authorities we interviewed tell us that labor inspections focus on detecting violations of minimum wage, overtime pay regulations and violations of written contracts. We found no evidence that minimum wages laws are enforced more strictly than overtime pay regulations, or vice-versa. As we note above, fines for violating minimum wage legislation can be larger than those for violating overtime pay regulations (a maximum of $500 \%$ of the wage for violating minimum wage laws but only $100 \%$ for violating overtime pay regulations). However, as most firms simply correct violations if they are found, and few firms pay fines, it is not likely that this difference in fines will be important in the decisions of firms. Overall, labor inspections appear to enforce both minimum wages and overtime legislation, although the effective penalties for violating either regulation are low.

The monthly minimum wage does not apply to part-time workers. Instead, in 2004 the government mandated a separate hourly minimum wage for part-time workers. Because employers are not required to pay some non-wage benefits for part-time workers, the part-time hourly minimum wage is set above the monthly minimum wage for fulltime workers (or, more specifically, the monthly minimum wage divided by the number of hours worked per month by a full-time worker). For this reason, it is not appropriate to compare the hourly wage of full-time workers to the hourly legal minimum wage for part-time workers when examining compliance. 
The minimum wage in China is low, overall, compared to average wages. Minimum wages have been increasing since 1995, but generally minimum wage increases tend to be lower than increases in average wages or per capita GDP (Su and Liu, 2006). Minimum wages generally cannot cover basic living expenses (Han and Wei, 2005; Su and Liu, 2006). A comparison of minimum wage/average wage ratio between China and OECD countries was made by Jia (2014). Since 2000, the minimum wage/average wage ratio in OECD countries has been increasing gradually, while this ratio of China has been decreasing sharply. As of 2009, this ratio in OECD countries was well above 35\%, while in China this ratio was only a little more than $20 \%$.

\section{Literature review}

There have been relatively few empirical studies examining evidence of noncompliance with minimum wage and overtime pay regulations among a wide range of Chinese firms. As noted in the last section, because of the complex nature of minimum wages in China and confusion about what should or should not be included as "earnings" when comparing earnings to minimum wages, this is not a trivial task. Fang and Lin (2013), using the annual Urban Household Survey from 2002 to 2009, find that the proportion of civilian employees (excluding self-employed and students) whose total monthly wage is below the minimum wage is $5.6 \%$. Yang et al. (2014), using a survey of internal migrants from 2011 to 2012, estimate that approximately 5\% of migrants earn at or below the monthly minimum wage.

While these nationally-representative empirical studies suggest broad compliance with minimum wage laws in China, there are several studies that present anecdotal evidence that compliance with minimum wages in China is far from complete (i.e., Rawski 2006; Li, 2007). Other studies present empirical evidence of possible non-compliance when hours of work are taken into account, but only for a sub-set of Chinese workers and firms. For example, Xie (2010) surveys 485 rural migrants in three cities in Jiangsu province in 2009, finding that the proportion of workers whose total monthly wage is below the monthly minimum wage is $3.9 \%$. However, he also notes that many rural migrants work more than the legally-mandated $40 \mathrm{~h}$ per week. To take into account overtime hours, Xie (2010) calculates an hourly wage and compares that to an implicit hourly minimum wage based on the monthly minimum wage divided by the number of hours worked by a full-time worker in a month, finding that over $25 \%$ of workers in his sample earn less than the hourly minimum wage when overtime hours are taken into account. When he also takes into account that overtime hours should be paid 1.5 times the regular minimum wage (and 2.0 times the regular minimum wage for weekend hours), the percent who earn less than the minimum wage increases to over $60 \%$.

Sun and Shu (2011) study rural migrants in 9 cities in Guangdong province in 2006, 2008, 2009 and 2010. They find that the proportion of workers whose monthly wage is less than the monthly minimum wage is $9.0,7.7,4.0$ and $4.2 \%$, respectively, in these 4 years. However, when they take into account overtime hours, they find that the proportion of workers whose hourly wage is below the implicit hourly minimum wage for full-time workers was 45.3, 33.3, 28.1 and 23.8\%. Du and Wang (2008) use data from five capital cities in Shanghai, Wuhan, Shenyang, Fuzhou and Xi'an in 2001 and 2005 and find that the monthly wage is below the monthly minimum wage for $11.2 \%$ of 
workers but that the hourly wage was below the implicit hourly minimum wage for full-time workers for $52.2 \%$ of workers.

Most of the empirical studies of the impact of recent minimum wage changes in China have focused on the potentially negative impact on employment. The evidence from research on the employment impacts of minimum wages in China is mixed, with some studies finding a negative effect, some finding no effect, and others finding a positive effect. When detected, negative employment effects tend to be relatively small. Whether or not a negative impact is found often depends on which types of workers or firms are examined. Generally, studies that focus on less-skilled workers are more likely to find a negative employment impact. For example, Fang and Lin (2013) find a negative employment effect for low-skilled workers, defined as those with a secondary school education or less, but no employment effect for more educated workers, for young adults but not older adults, for women but not men, and for workers whose earnings were between the old and new minimum wages. Jia (2014) find a negative impact on the employment of women but not men. Several studies find evidence that higher minimum wages led to a decrease in the employment of rural migrants (who tend to be less skilled) but not for permanent urban residents (Ding, 2010; Wang and Gunderson, 2011, 2012; Li and He, 2010; Fang and Lin, 2013). ${ }^{9}$ Ma et al. (2012) find that higher minimum wages are more likely to affect workers in labor intensive firms and firms with lower asset per worker ratios. Sun et al. (2013) use firm-level data to show that increases in the minimum wage are likely to have a larger impact on firms dependent on exports, firms which also tend to be labor intensive.

Many studies also find regional differences. For example, Fang and Lin (2013) find that higher minimum wages have a significant negative impact on the employment of some types of workers in the more-developed and faster growing Eastern regions, a lagged negative impact in the Central regions, and no statistically significant impact in any type of workers in the least-developed West. Ni et al. (2008)) also find negative employment effects in the Eastern provinces but not in the West. Ding (2010) finds a larger negative employment impact of higher minimum wages in the most-developed Guangdong province compared to Fujian province. In contrast, Wang and Gunderson (2011, 2012) find no significant negative employment effect on private sector employment in the East, although Wang and Gunderson (2012) find evidence of a small lagged negative employment effect on privately-owned firms in the Central region of China.

Regional differences may be due to the mix of state-owned and privately-owned businesses in the different regions. For example, while Wang and Gunderson (2011) do not find a significant negative impact of minimum wages among private sector firms in Eastern China, they do find evidence of a positive employment impact in state-owned firms. Wang and Gunderson (2011) argue that the positive employment effect in stateowned firms may be because these firms act as monopsonists. The East region has a much higher percentage of privately-owned firms than the Central or Western Region, and this might explain the lack of a negative employment effect in the East found by many studies that do not distinguish between state-owned and privately-owned firms. This suggests that it is important to present results separately for firms with different ownership, something we do in our paper.

As with the impact of minimum wages on employment, the results of studies of the impact of minimum wages on wages in China are mixed. Wang and Gunderson (2012) 
find that higher minimum wages had no significant impact on aggregate wages in Eastern China. Yang and Gunderson (2014) find statistically significant positive impacts of minimum wages on the monthly wages of migrant workers in Western China but not Eastern China, and among rural migrants but not urban migrants. They attribute the positive effect of minimum wages in the West to the prevalence of state-owned firms in that region.

Yang and Gunderson (2014) also note that many migrant workers work more than the full-time maximum of $40 \mathrm{~h}$ per week, often without additional pay. While Yang and Gunderson (2014) do not find evidence of a negative employment effect of minimum wages, they do find evidence that faced with higher minimum wages, employers extend working hours. Jia (2014) also present evidence that higher minimum wages cause firms in Eastern China to increase hours worked. Yang and Gunderson (2014) contend that workers who are forced to work additional overtime hours are paid less than the legal minimum wage. To support this contention they present evidence that higher minimum wages are correlated with lower hourly wages.

\section{Data}

The data used in this paper are firm-employee matched data for the year 2009. These data were collected in 2010 by a team from Beijing Normal University headed by Shi Li and including Linxiang Ye, two co-authors of this article. To construct the sample of firms, 6 provinces from different regions in China were chosen. These provinces are Guangdong, Shandong, Beijing and Jiangsu in the East, Hubei in the Central and Shaanxi in the West. Then in each province three to five prefectural cities were chosen. Generally, the capital prefectural city of the province, ${ }^{10}$ one medium-developed prefectural city, and one least-developed prefectural city are included from each province. Last, in every prefectural city, enterprises were randomly chosen. After cleaning the data, we have data on 2835 enterprises from 6 provinces 39 prefectural cities, and 249 counties. $80 \%$ of the workers in our sample work in Eastern provinces, $11.6 \%$ in the Central province of Hubei and $2.8 \%$ in the Western province of Shanxi.

The majority of firms in the survey are in manufacturing (52.7\% of firms, representing $65.9 \%$ of workers). Of workers in manufacturing, $8.2 \%$ are in apparel and textile manufacturing, $6.9 \%$ in electronic equipment manufacturing and $50.8 \%$ are in other manufacturing. Our sample also includes workers in firms in wholesale and retail trade (10.6\% of workers), construction (8.5\%), transportation, storage and postal services (7.3\%), financial services (2.6\%) and electricity, gas and water (5.1\%). ${ }^{11}$

The number of employees in each firm surveyed ranges from 1 to 41,500. 17\% of firms have fewer than 20 workers, $50 \%$ of firms have fewer than 91 workers, $90 \%$ of firms have fewer than 729 workers, and less than 3\% of firms have more than $2373 \mathrm{em}$ ployees. $77 \%$ of firms are classified as small firms (below 300 workers), 20.3\% as medium sized firms (between 300 and 2000 workers), and 2.7\% as large firms (more than 3,000 workers). For small firms, all workers in each firm are surveyed, except for those who were hired or fired in 2009. For medium and large firms, where there are many people in the same position/occupation, a sample of employees at each position/ occupation were surveyed. Our data set includes information on 521,501 full-time employees. In general, our data captures only formal sector firms. 
Enterprise level variables include: ownership (Chinese, private, state, foreign-owned, etc.), the average number of employees, enterprise size, revenue, profit, total costs, labor cost, wage expenditure, payment to workers social insurance, training expenditure, labor protection expenditure, and a housing expense allowance. Employee-level variables are defined for the entire year of 2009 and include: wages, sex, age, education attainment, occupation, position, the type of employment, the type of labor contract, are or are not the member of a labor union, wages, and working hours.

Our employee-level data provide not only total yearly wage but also its different wage components: basic wage, bonus, supplements, and overtime pay. Bonuses can differ between individuals and are based on the productivity of workers. Supplements are given to all workers with certain job characteristic, such as those who work night hours or who have more years of tenure in the firm. Information on pay is the yearly total. We divide this yearly total by 12 to construct a monthly pay variable. In comparing wages to the legal minimum wage it is important to use the correct measure of wages. Legally, the wage compared to the minimum wage should include the basic wage plus bonus plus some, but not all, supplements. Overtime pay, the employer contribution to social insurance, and some legally-mandated supplements should be excluded. Other wage supplements that should be excluded when comparing wages to the minimum wage include those for working the night shift and working under dangerous or uncomfortable working conditions. Wage supplements that should be included when comparing wages to the minimum wage are those that are not legally mandated, and include those for medical and health benefits, for tenure, meal allowances, transportation supplements, supplements for books and newspapers, and cost of living adjustments. However, our data only report total supplements paid to workers. That is, we cannot distinguish between supplements that are legally required to be included in the minimum wage and those legally excluded. Because we cannot distinguish which part of reported supplements should or should not be included when comparing to the minimum wage, when we calculate the proportion of full-time workers earning less than the monthly minimum wage, we present two estimates: the proportion earning less than the basic wage plus bonus (an upper bound) and the proportion earning less than the basic wage plus bonus plus supplements (a lower bound).

We have noted that the existing literature suggests that while employers pay most workers the monthly legal minimum wage, many may violate over-time pay regulations. Our data allow us to separate out overtime pay from regular pay so that we can obtain separate and precise estimates of non-compliance with minimum wage and overtime pay regulations.

Table 1 presents the distribution of these components of the wage for workers in our sample with different characteristics. Overall, $65 \%$ of the wage paid to workers is classified as the basic wage, $20 \%$ of wages are attributed to bonuses, $7.6 \%$ from overtime pay, and $6.7 \%$ from supplements. Less-skilled workers (younger, less-educated and less experienced) receive a higher proportion of their pay as overtime pay and a lower proportion as bonus. Workers in private firms with owners from Hong Kong, Taiwan, Macao or a foreign country are also more likely to receive a higher proportion of their pay as overtime pay and a lower proportion as bonus. Workers in state-owned firms and more-skilled workers receive a larger fraction of their pay from bonuses and a smaller fraction from overtime pay. 
Table 1 Percent of total earnings (including overtime pay) from different sources

\begin{tabular}{|c|c|c|c|c|c|}
\hline & $\begin{array}{l}\text { Basic } \\
\text { wage }\end{array}$ & Bonus & Supplements & $\begin{array}{l}\text { Overtime } \\
\text { pay }\end{array}$ & $\begin{array}{l}\text { The percent } \\
\text { of obs }\end{array}$ \\
\hline All & 65.3 & 20.4 & 6.7 & 7.6 & 100 \\
\hline \multicolumn{6}{|l|}{ Gender } \\
\hline Male & 64.3 & 21.3 & 7.1 & 7.4 & 60.7 \\
\hline Female & 66.8 & 19.1 & 6.1 & 8.0 & 39.3 \\
\hline \multicolumn{6}{|l|}{ Educational attainment } \\
\hline College or above & 64.4 & 23.9 & 8.1 & 3.6 & 9.8 \\
\hline Junior college & 65.5 & 22.5 & 7.3 & 4.7 & 16.4 \\
\hline High school & 64.9 & 20.5 & 7.0 & 7.7 & 42.9 \\
\hline Junior high school or below & 66.1 & 18.1 & 5.5 & 10.2 & 30.9 \\
\hline \multicolumn{6}{|l|}{ Age cohort } \\
\hline Age $16-20$ & 61.0 & 17.3 & 6.8 & 14.9 & 4.9 \\
\hline Age $21-25$ & 64.2 & 19.7 & 7.2 & 8.8 & 15.9 \\
\hline Age $26-30$ & 65.2 & 20.1 & 6.9 & 7.8 & 19.2 \\
\hline Age $31+$ & 65.9 & 21.0 & 6.5 & 6.6 & 60.1 \\
\hline \multicolumn{6}{|l|}{ Experience cohort } \\
\hline Experience 1-3 & 64.9 & 17.9 & 7.0 & 10.2 & 26.8 \\
\hline Experience 4-6 & 64.4 & 19.9 & 6.5 & 9.1 & 15.3 \\
\hline Experience 7-9 & 68.0 & 18.2 & 6.0 & 7.7 & 9.6 \\
\hline Experience $10+$ & 65.2 & 22.4 & 6.7 & 5.7 & 48.3 \\
\hline \multicolumn{6}{|l|}{ Position in firm } \\
\hline Office work & 67.2 & 18.3 & 7.0 & 7.5 & 10.3 \\
\hline Manual worker with junior skill certificate & 67.0 & 20.3 & 5.0 & 7.7 & 14.1 \\
\hline Manual worker with no skill certificate & 65.8 & 17.9 & 6.4 & 9.8 & 40.2 \\
\hline Others & 62.9 & 24.0 & 7.4 & 5.8 & 35.4 \\
\hline \multicolumn{6}{|l|}{ Firm ownership } \\
\hline State funded firm & 56.4 & 28.4 & 10.8 & 4.5 & 15.4 \\
\hline Non-state domestic funded firm & 67.4 & 20.6 & 5.7 & 6.3 & 61.5 \\
\hline HongKong,Taiwan,Macao funded firm & 67.0 & 10.6 & 7.7 & 14.6 & 7.8 \\
\hline Foreign funded firm & 64.9 & 16.8 & 6.1 & 12.3 & 15.4 \\
\hline \multicolumn{6}{|l|}{ Firm size } \\
\hline Large & 58.3 & 28.0 & 7.0 & 6.7 & 29.5 \\
\hline Medium & 65.1 & 19.3 & 6.9 & 8.6 & 43.3 \\
\hline Small & 73.2 & 14.0 & 6.0 & 6.9 & 27.3 \\
\hline \multicolumn{6}{|l|}{ Industry sectors } \\
\hline Apparel and textile products manufacturing & 67.2 & 16.4 & 3.6 & 12.9 & 8.2 \\
\hline $\begin{array}{l}\text { Communications equipment and computer } \\
\text { manufacturing other electronic equipment }\end{array}$ & 59.6 & 15.0 & 8.9 & 16.4 & 6.9 \\
\hline Other manufacturing & 64.0 & 21.5 & 6.7 & 7.8 & 50.8 \\
\hline Electricity, gas and water production & 57.5 & 27.0 & 11.8 & 3.7 & 5.1 \\
\hline Construction & 77.9 & 13.4 & 5.6 & 3.1 & 8.5 \\
\hline Transportation, storage and post service & 59.5 & 24.9 & 8.6 & 7.1 & 7.3 \\
\hline Wholesale and retail trade (commerce) & 71.8 & 19.6 & 4.6 & 4.1 & 10.6 \\
\hline Financial service & 56.3 & 27.4 & 5.0 & 11.3 & 2.6 \\
\hline
\end{tabular}


Table 1 Percent of total earnings (including overtime pay) from different sources (Continued)

\begin{tabular}{lrrrrr}
\hline Region & & & & & \\
Beijing & 62.7 & 24.3 & 7.3 & 5.6 & 14.0 \\
Jiangsu & 65.2 & 19.3 & 5.9 & 9.6 & 28.1 \\
Shandong & 68.2 & 21.5 & 5.3 & 5.0 & 28.9 \\
Hubei & 59.5 & 26.6 & 8.8 & 5.1 & 16.6 \\
Guangdong & 63.5 & 9.9 & 10.6 & 15.9 & 9.6 \\
Shaanxi & 90.1 & 0.0 & 0.0 & 9.9 & 2.8 \\
\hline
\end{tabular}

The basic wage plus bonus pay system is a type of "pay-for-performance" where the performance-related compensation does not permanently increase base pay but must be re-earned to receive again. Pay-for-performance systems may promote worker productivity through two main mechanisms. First, they provide an incentive for employees to work more efficiently. Second, they can help attract and retain highly productive workers who may earn more than in firms where every worker receives the average value of their marginal product (Durham and Bartol, 2003).

Since the implementation of its economic reforms in 1978, pay-for-performance wage systems have been introduced widely and intensively in China (Warner, 1996). "As a critical part of the wage system revolution, an increasing number of public and private organizations in China have introduced PFP. Over the 15-year period from 1978 to 1993, piecework wage and bonuses as a percentage of total pay of Chinese employees increased from 3.1 to $23.3 \%$. In the traditional payment structure applied before the Chinese reforms, employees received increasing pay and benefits (including welfare housing) according to their tenure, regardless of their performance level, and job security was guaranteed, thus providing workers with an 'iron rice bowl'...PFP was introduced to break the idea of the 'iron rice bowl', as well as the traditional compensation ideology by creating a strong link between pay and performance." (Du and Choi, 2010, p. 672).

$\mathrm{Du}$ and Choi (2010) argue that in China PFP can be more beneficial to domestic firms than to foreign firms. This is in part because there is no tradition of an "iron rice bowl" in foreign-owned firms. In addition, foreign-owned firms typically apply their existing Human Resource practices that are "characterized by consistent rules and systematic processes as well as by regular feedback directed to each employee," whereas domestically-owned firms "typically do not provide (or even informal) performance reviews" (p. 676). Du and Choi (2010) find, as do we, that pay-for-performance bonuses are more intensively used in domestically-owned firms compared to foreign-owned firms. As noted, foreign-owned firms in our data pay a much lower percent of their pay in bonuses. Foreign-owned firms, on the other hand, are less likely to pay bonuses and instead pay a larger proportion of wages as overtime pay.

As we show later in the paper, the bonus-based pay-for-performance structure provides an additional margin by which Chinese firms can respond to an increase in minimum wages. Specifically, we present evidence that many Chinese firms set the basic wage equal to the legal minimum wage but pay most workers a bonus that results in the total wage being higher than the minimum. Then, when minimum wages increase, employers are able to raise base wages but lower bonuses in order to keep total wages near the marginal productivity of labor. 
In addition to the matched firm-employee data, we also collected data at the most detailed geographic level (county level) on the level of the minimum wage, the dibao (a cost of living index), and GDP per capita. These data are obtained from local government bulletins and websites of the executive branch of human resources and social security department.

\section{Compliance with legal minimum wages and overtime pay regulations in China}

5.1 Who earns less than the monthly minimum wage?

In comparing wages to minimum wages, the regulations make it clear the wage includes any bonuses but excludes overtime pay and legally-mandated supplements. Our data allow us to exclude overtime pay and include bonuses when we calculate the wage. As noted above, we cannot distinguish between supplements that are legally required to be included in the minimum wage and those legally excluded. For this reason we construct two measures of the wage when comparing to the minimum wage: (1) the basic wage plus bonuses and (2) the basic wage plus bonuses plus supplements. The proportion of workers whose basic wage plus bonus is less than the minimum wage will be an overestimate of the true proportion earning less than the minimum (the estimated proportion will be an upper bound), and the proportion earning less than the basic wage plus bonus plus supplements will be an underestimate of the true proportion earning less than the minimum (a lower bound estimate of the proportion earning below the minimum wage). The results of this analysis are presented in Table 2

Compared to other developing countries, we find that very few full-time workers earn less than the monthly legal minimum wage in China. Our upper bound estimate of the number of workers earning below the minimum wage is $3.4 \%$; our lower bound is $2.1 \%$. This is similar to the proportion of workers earning below the monthly legal minimum wage found in other studies using Chinese data. On the other hand, $30 \%$ of formal sector workers in Costa Rica earn below the minimum wage (Gindling and Trejos, 2010), 23\% in Nicaragua (Alaniz et al. 2011), almost 20\% in Chile (Kanbur et al. 2013), and $45 \%$ in Paraguay (Cunningham, 2007). Bhorat et al. (2010) find that $45 \%$ of covered workers get paid wages below the legislated minimum wage in South Africa, Belser and Rani (2010) report that $25.3 \%$ of workers earn below national minimum wage floor and $27.2 \%$ of workers below state-level minimum wages in India. Lemos (2006) reports that the percent of workers whose wage is below the minimum wage in the formal sector in Brazil is between 5 and 10\%, and Harrison and Scorse (2003) report only about half of all plants paid average wages which exceeded the statutory regional minimum for production workers in Indonesia. In nine of the 11 developing economies from Asia, Latin America, and Africa studied by Rani et al. (2013), non-compliance rates are above $30 \%$. Only in Vietnam are non-compliance rates as low as those in China, at about 5\%. Even in the United States, one study found that over $25 \%$ of workers in textile firms in Los Angeles earn less than the minimum wage (Weil, 2005).

The proportion of workers earning less than the minimum wage in China is higher for women than men, for younger and less-experienced workers, and for workers with less education. ${ }^{12}$ The proportion of workers earning below the minimum wage is also substantially higher in firms with owners from Hong Kong, Taiwan, and Macao, and in 
Table 2 Percent of workers whose monthly wage is below the monthly legal minimum wage

\begin{tabular}{|c|c|c|c|}
\hline & $\begin{array}{l}\text { Basic wage }+ \text { bonus } \\
\text { is below the MW }\end{array}$ & $\begin{array}{l}\text { Basic wage + bonus + } \\
\text { supplements is below MW }\end{array}$ & $\begin{array}{l}\text { The } \\
\text { percent of } \\
\text { obs. }\end{array}$ \\
\hline All & 3.4 & 2.1 & 100 \\
\hline \multicolumn{4}{|l|}{ Gender } \\
\hline Male & 2.7 & 1.8 & 60.5 \\
\hline Female & 4.5 & 2.6 & 39.5 \\
\hline \multicolumn{4}{|l|}{ Educational attainment } \\
\hline College or above & 1.1 & 0.8 & 9.8 \\
\hline Junior college & 1.7 & 1.1 & 16.4 \\
\hline High school & 2.8 & 1.7 & 42.9 \\
\hline Junior high school or below & 5.4 & 2.9 & 30.9 \\
\hline \multicolumn{4}{|l|}{ Age cohort } \\
\hline Age 16-20 & 6.0 & 3.8 & 4.9 \\
\hline Age $21-25$ & 4.1 & 2.3 & 15.9 \\
\hline Age 26-30 & 3.2 & 1.8 & 19.2 \\
\hline Age $31+$ & 2.9 & 1.7 & 60.1 \\
\hline \multicolumn{4}{|l|}{ Experience cohort } \\
\hline Experience 1-3 & 5.1 & 2.9 & 26.8 \\
\hline Experience 4-6 & 3.4 & 1.7 & 15.3 \\
\hline Experience 7-9 & 2.8 & 1.4 & 9.6 \\
\hline Experience $10+$ & 2.3 & 1.5 & 48.3 \\
\hline \multicolumn{4}{|l|}{ Position in firm } \\
\hline Office work & 5.2 & 3.9 & 10.3 \\
\hline Manual worker with junior skill certificate & 1.8 & 1.1 & 14.1 \\
\hline Manual worker with no skill certificate & 5.1 & 2.8 & 40.2 \\
\hline Others & 1.7 & 1.2 & 35.4 \\
\hline \multicolumn{4}{|l|}{ Firm ownership } \\
\hline State funded firm & 2.8 & 1.5 & 15.4 \\
\hline Non-state domestic funded firm & 2.9 & 1.9 & 61.5 \\
\hline HongKong, Taiwan, Macao funded firm & 9.4 & 4.3 & 7.8 \\
\hline Foreign funded firm & 2.3 & 1.2 & 15.4 \\
\hline \multicolumn{4}{|l|}{ Firm size } \\
\hline Large & 1.8 & 1.4 & 29.5 \\
\hline Medium & 3.9 & 2.0 & 43.3 \\
\hline Small & 4.0 & 2.3 & 27.3 \\
\hline \multicolumn{4}{|l|}{ Region } \\
\hline Beijing & 1.9 & 1.3 & 14.0 \\
\hline Jiangsu & 1.5 & 0.7 & 28.1 \\
\hline Shandong & 2.8 & 2.4 & 28.9 \\
\hline Hubei & 1.3 & 0.6 & 16.6 \\
\hline Guangdong & 15.4 & 6.9 & 9.6 \\
\hline Shaanxi & 3.4 & 3.4 & 2.8 \\
\hline \multicolumn{4}{|l|}{ Ascending sort by firm revenue per worker } \\
\hline The first quintile & 6.7 & 2.7 & 14.4 \\
\hline The second quintile & 5.5 & 2.9 & 17.4 \\
\hline
\end{tabular}


Table 2 Percent of workers whose monthly wage is below the monthly legal minimum wage (Continued)

\begin{tabular}{|c|c|c|c|}
\hline The third quintile & 4.2 & 2.4 & 25.4 \\
\hline The fourth quintile & 3.7 & 2.2 & 24.2 \\
\hline The fifth quintile & 3.3 & 1.9 & 18.6 \\
\hline \multicolumn{4}{|l|}{ Industry sectors } \\
\hline Apparel and textile products manufacturing & 2.2 & 1.3 & 7.8 \\
\hline $\begin{array}{l}\text { Communications equipment and computer } \\
\text { manufacturing other electronic equipment }\end{array}$ & 4.9 & 1.6 & 6.9 \\
\hline Other manufacturing & 3.7 & 2.3 & 51.0 \\
\hline Electricity, gas and water production & 3.5 & 2.1 & 5.2 \\
\hline Construction & 1.5 & 0.9 & 8.7 \\
\hline Transportation, storage and post service & 4.5 & 2.9 & 7.3 \\
\hline Wholesale and retail trade (commerce) & 1.9 & 0.7 & 10.7 \\
\hline Financial service & 2.7 & 2.5 & 2.5 \\
\hline
\end{tabular}

Guangdong province, although workers in these firms represent a small fraction of the workers in our sample (less than 10\%). Even for workers with lower productivity, the percent earning less than the minimum wage is low compared to other countries. For example, even for workers with the least skills-younger workers and those with less education and experience-the proportion earning below the minimum wage is less than $10 \%$ when we consider only the basic wage plus bonus, and less than $5 \%$ once we include wage supplements. ${ }^{13}$

\subsection{Compliance with overtime pay regulations}

As noted previously, workers who work more than $40 \mathrm{~h}$ per week should be paid at least 1.5 times their regular hourly wage for the overtime hours that they work (2.0 times on weekends and 3.0 times on holidays). Our data allow us to separate overtime pay from regular pay (although it does not identify if these overtime hours are on weekends or holidays). To examine whether employers are complying with overtime pay regulations, we examine the following statistics: what percent of workers work more than $40 \mathrm{~h}$ per week but are not paid any overtime pay, what percent of workers are paid less than 1.5 times the legal minimum wage for the overtime hours that they work, what percent of workers are paid less than 1.5 times their regular pay for the overtime hours that they work (Table 3).

Over $41 \%$ of workers in our sample work overtime hours. Of these workers, a substantial fraction did not receive any overtime pay. Almost $29 \%$ of workers who work overtime (12\% of all workers) received no overtime pay even though they worked overtime hours. Over $40 \%$ of workers who worked overtime hours (17\% of all workers) received less than 1.5 times the legal minimum wage for their overtime hours. Finally, $69.5 \%$ of workers who work overtime hours $(28 \%$ of all workers) earned less than 1.5 times their regular pay for overtime hours. In summary, while we find evidence of broad compliance with legal minimum wage laws 
Table 3 Percent of workers who do not receive legally-mandated overtime pay

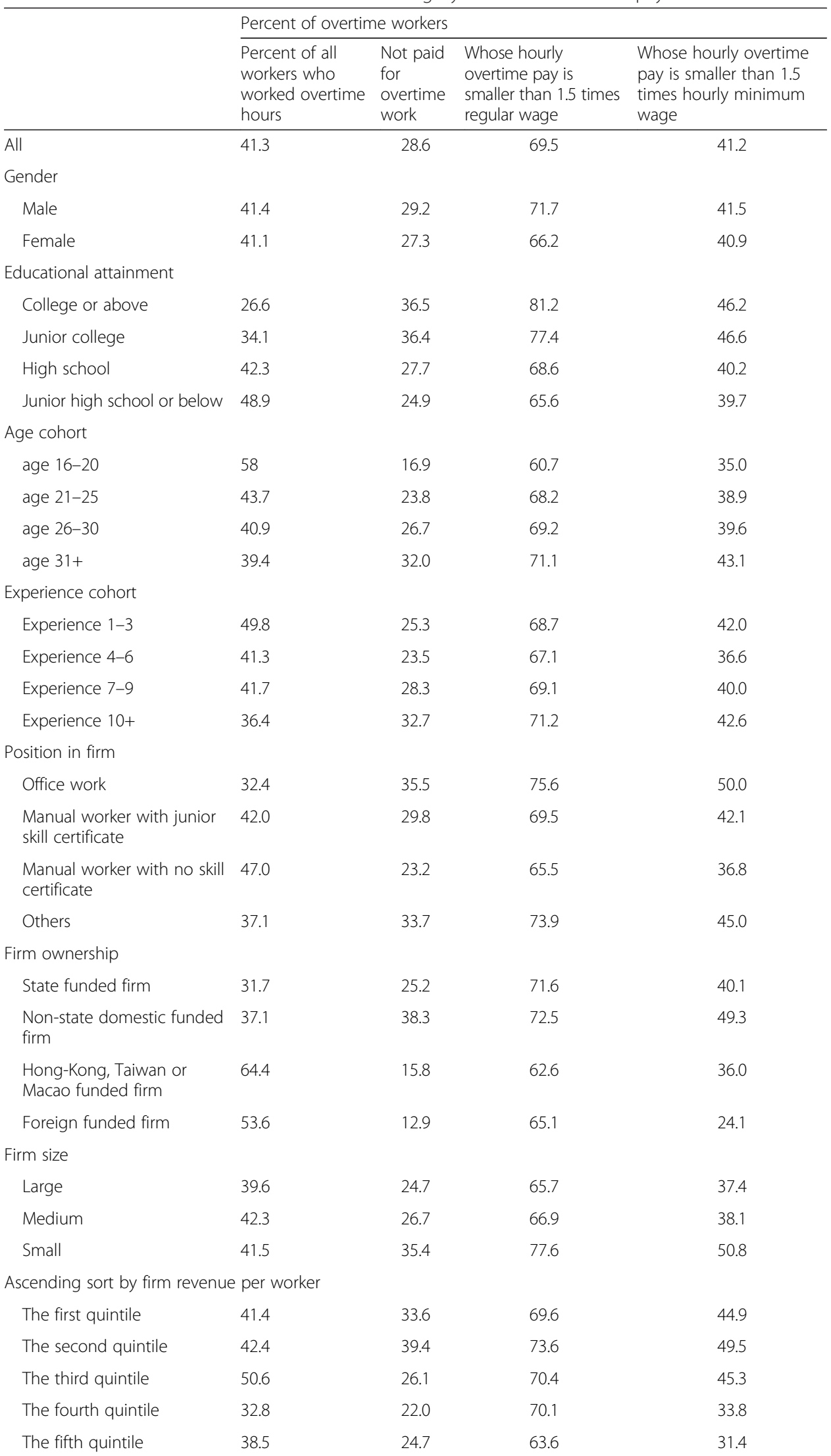


Table 3 Percent of workers who do not receive legally-mandated overtime pay (Continued)

\begin{tabular}{|c|c|c|c|c|}
\hline \multicolumn{5}{|l|}{ Industry sectors } \\
\hline $\begin{array}{l}\text { Apparel and textile } \\
\text { products manufacturing }\end{array}$ & 50.4 & 23.8 & 64.9 & 33.9 \\
\hline $\begin{array}{l}\text { Communications } \\
\text { equipment and computer } \\
\text { manufacturing other } \\
\text { electronic equipment }\end{array}$ & 62.8 & 13.7 & 65.0 & 30.9 \\
\hline Other manufacturing & 45.2 & 33.2 & 70.4 & 48.0 \\
\hline $\begin{array}{l}\text { Electricity, gas and water } \\
\text { production }\end{array}$ & 30.6 & 29.4 & 71.6 & 40.2 \\
\hline Construction & 27.5 & 44.7 & 89.1 & 53.1 \\
\hline $\begin{array}{l}\text { Transportation, storage and } \\
\text { post }\end{array}$ & 42.2 & 13.3 & 69.2 & 17.5 \\
\hline $\begin{array}{l}\text { Wholesale and retail } \\
\text { trade(commerce) }\end{array}$ & 21.4 & 22.0 & 58.4 & 29.9 \\
\hline Financial service & 22.7 & 24.2 & 67.4 & 30.4 \\
\hline \multicolumn{5}{|l|}{ Region } \\
\hline Beijing & 34.2 & 20.2 & 64.3 & 28.4 \\
\hline Jiangsu & 52.1 & 18.8 & 71.8 & 30.3 \\
\hline Shandong & 33.5 & 49.0 & 76.1 & 65.1 \\
\hline Hubei & 30.6 & 32.7 & 69.3 & 37.6 \\
\hline Guangdong & 59.9 & 17.9 & 58.3 & 40.6 \\
\hline Shaanxi & 43.6 & 56.7 & 73.2 & 58.3 \\
\hline
\end{tabular}

in China, we also find evidence of substantial non-compliance with overtime pay regulations in China.

Table 3 presents evidence that all types of workers are likely to face overtime pay violations. A high proportion of workers of all education, age, and gender are not paid the legally-mandated wage for overtime work. Workers who work overtime but paid any additional wage beyond their regular pay work in both state-owned and privatelyowned firms. Workers in firms with owners from Hong Kong, Taiwan, Macao, and foreign countries are more likely to work overtime and are also more likely to be paid for overtime hours, although the overtime pay is still generally less than 1.5 times the regular wage.

We have presented evidence that while almost all Chinese firms comply with minimum wage laws, many do not comply with overtime pay regulations. As noted in a previous section of this paper, penalties for violating minimum wage and overtime laws in China are small. In the vast majority of cases, firms found to be in violation of minimum wage or overtime pay regulations are simply required to pay workers the back pay owed; no additional fines are imposed. Further, we could find no evidence that minimum wage laws are enforced more strictly than overtime pay regulations. Given the low cost of violating these regulations and equal enforcement efforts, it is not likely that the difference in compliance is due to differential enforcement of minimum wage and overtime pay regulations.

If differential enforcement is not the reason for differential compliance with minimum wage and overtime laws, then differential compliance is likely due to social or 
cultural norms. One thing to remember is that the opening of the Chinese socialist planned economy to private firms is relatively recent, and labor regulation of private firms in China is even more recent. We have noted that the first Chinese minimum wage regulations were promulgated only in 1994. In the absence of strong enforcement actions, it may take time for a culture of compliance with the entire labor code to develop. For several reasons, we believe that it is reasonable to expect that a culture of compliance with minimum wages has developed in China, but a culture of compliance with overtime pay has not. Prior to 1994 wages for workers in government-owned firms, in an economy dominated by government-owned firms, were set by government decree. It required relatively little change in social norms for workers and employers to accept that the government should have a role in setting wages in the new private sector. ${ }^{14}$ On the other hand, there was no history of a $40 \mathrm{~h}$ work week in China prior to the 1994 labor regulations. Prior to the 1994 labor regulations, the legal work week in China was $48 \mathrm{~h}$ per week ( $8 \mathrm{~h}$ per day, 6 days per week). The 1994 regulations even allowed firms some flexibility in implementing the change in working hour regulations; with the permission of labor authorities, some firms were allowed to delay implementation of the $40 \mathrm{~h}$ work week until 1997. In addition, in rural and agricultural areas, the home of many Chinese manufacturing workers, working hours may vary by season, and it was and is common to work more than 5 days per week and more than $8 \mathrm{~h}$ per day during some seasons of the year. Rural migrants employed at the urban manufacturing firms may therefore expect to work more than $40 \mathrm{~h}$ per week. In particular, given a historical $48 \mathrm{~h}$ work week, employees may not protest if asked to work a $48 \mathrm{~h}$ week. Even if they are aware that they should be paid extra for extra work, there is little history in China of paying more than the regular wage for overtime hours. Prior to the 1994 labor regulations, firms were required only to pay the same wage for overtime hours as for regular hours. Thus, employees may still not be aware that overtime pay is required to be greater than the regular pay.

Table 4 Percent of workers who do not receive legally-mandated overtime pay, by hours worked

\begin{tabular}{llllc}
$\begin{array}{l}\text { Weekly } \\
\text { working } \\
\text { hours }\end{array}$ & $\begin{array}{l}\text { Not paid for } \\
\text { overtime } \\
\text { work }\end{array}$ & $\begin{array}{l}\text { Whose hourly overtime pay is } \\
\text { smaller than 1.5 times regular } \\
\text { wage }\end{array}$ & $\begin{array}{l}\text { Whose hourly overtime pay is smaller } \\
\text { than 1.5 times hourly minimum wage }\end{array}$ & $\begin{array}{l}\text { Percent } \\
\text { of obs. }\end{array}$ \\
\hline$[40,42]$ & 38.6 & 62.3 & 41.7 & 36.85 \\
{$[42,44]$} & 24.7 & 67.8 & 34.2 & 15.18 \\
{$[44,46]$} & 31.8 & 75.6 & 44.7 & 9.9 \\
{$[46,48]$} & 30.7 & 81 & 52.9 & 13.47 \\
{$[48,50]$} & 14.6 & 64.4 & 29.7 & 10.12 \\
{$[50,52]$} & 8.6 & 74.9 & 39.1 & 3.53 \\
{$[52,54]$} & 16.4 & 78.9 & 28.6 & 2.29 \\
{$[54,56]$} & 16.9 & 82.9 & 47.7 & 2.19 \\
{$[56,58]$} & 9 & 79 & 44.9 & 1.64 \\
{$[58,60]$} & 8.2 & 77.4 & 49.6 & 1.84 \\
$>60$ & 14 & 81.1 & 47.4 & 2.98 \\
\hline
\end{tabular}


Table 4 presents the proportion of workers who do not receive mandated overtime pay according to the number of overtime hours that they work. There is a clear discontinuity at $48 \mathrm{~h}$ per week. A substantial proportion of workers (around 30\% of those who work overtime hours) work up to $8 \mathrm{~h}$ of overtime without pay, while a much smaller proportion (closer to 15\%) work more than $48 \mathrm{~h}$ per week without additional pay. This evidence is consistent with the view that workers are willing to work a few more hours without pay (at least up to the pre-1994 work week of $48 \mathrm{~h}$ per week) but may balk at working a large number of hours without pay. On the other hand, the proportion of workers earning less than $150 \%$ the regular wage or the minimum wage does not depend on the number of overtime hours worked, suggesting that this legal requirement has not become the social norm.

\section{Who is likely to be affected by minimum wages?}

In the last section we presented evidence that the monthly minimum wage is generally complied with in China, although overtime pay regulations are not. In this section we present evidence that, despite widespread compliance with the monthly minimum wage, the wages of relatively few workers in China are likely to be affected by legal minimum wages.

\subsection{Who earns the minimum wage in China?}

We find that the relationship between the monthly minimum wage and the wages paid to workers depends on what wage we consider. Monthly minimum wages appear to be taken into consideration by many firms when setting the "basic wage." However, many workers also receive bonuses. Bonuses are part of the regular wage and are based on productivity and can vary by worker. We find that as minimum wages increase from one region to the next, the basic wage increases but bonuses decrease, so that, overall, total wages are not correlated with the level of minimum wages.

The basic wage of almost $5 \%$ of all full-time workers is exactly equal to the minimum wage for those workers, and the basic wage for $9.3 \%$ of all workers is between the minimum wage and $110 \%$ of the minimum wage (Table 5). These are surprisingly high percentages and suggest that firms consider the minimum wage when setting the basic wage. However, once supplements and bonuses are taken into account, this percentage is much smaller; the total full-time wage of fewer than $1 \%$ of the workers in our sample is exactly the minimum wage. The average increase in the minimum wage is around 10\% (Wang, 2012), so looking at workers earning between the minimum wage and $110 \%$ of the minimum wage is an estimate of the workers likely to be affected by minimum wage changes. By this measure, we estimate that only between 2.1 and $3.3 \%$ of workers will be affected by increases in the minimum wage. Our evidence suggests that many firms set the basic wage at the monthly minimum and then adjust the monthly wages of workers upward to the market wage for that worker based on the performance of that worker. Thus, the evidence suggests that the minimum wage does act as a wage floor for workers and firms but that the market wage of most workers in our sample are above the minimum wage. 
Table 5 Proportion of workers whose wage equals the minimum wage plus 10\%: comparisons to the basic wage and two measures of the total wage

\begin{tabular}{|c|c|c|c|c|c|c|}
\hline & \multicolumn{2}{|c|}{ Basic wage } & \multicolumn{2}{|c|}{$\begin{array}{l}\text { Basic wage }+ \\
\text { bonus }\end{array}$} & \multicolumn{2}{|c|}{$\begin{array}{l}\text { Basic wage + } \\
\text { bonus }+ \\
\text { supplements }\end{array}$} \\
\hline & $=\mathrm{MW}$ & {$[1,1.1] \mathrm{MW}$} & $=\mathrm{MW}$ & {$[1,1.1] \mathrm{MW}$} & $=\mathrm{MW}$ & {$[1,1.1] \mathrm{MW}$} \\
\hline All & 4.9 & 9.3 & 1.3 & 3.3 & 0.8 & 2.1 \\
\hline \multicolumn{7}{|c|}{ Gender } \\
\hline Male & 4.0 & 7.7 & 1.0 & 2.3 & 0.6 & 1.4 \\
\hline Female & 6.3 & 11.9 & 1.7 & 4.7 & 1.1 & 3.1 \\
\hline
\end{tabular}

Educational attainment

College or above
Junior college
High school
Junior high school or below

Age 16-20

Age 21-25

Age 26-30

Age $31+$

Experience 1-3

Experience 4-6

Experience 7-9

Experience 10+

Office work

Manual worker with junior skill certificate Manual worker with no skill certificate

Others

Large
Medium
Small

Small

State funded firm

Non-state domestic funded firm

HongKong, Taiwan, Macao funded firm

Foreign funded firm

$\begin{array}{llllll}1.9 & 3.4 & 0.4 & 0.8 & 0.1 & 0.2 \\ 2.9 & 5.5 & 0.5 & 1.3 & 0.2 & 0.7 \\ 4.8 & 9.4 & 1.1 & 2.9 & 0.6 & 1.7 \\ 7.1 & 13.2 & 2.4 & 5.5 & 1.7 & 3.9\end{array}$

Age cohort

$\begin{array}{llllll}7.4 & 14.8 & 2.1 & 7.4 & 1.4 & 4.1 \\ 4.3 & 9.3 & 1.2 & 3.4 & 0.6 & 2.0 \\ 4.3 & 8.3 & 1.2 & 2.8 & 0.6 & 1.7 \\ 5.0 & 9.2 & 1.3 & 3.0 & 0.9 & 2.1\end{array}$

Experience cohort

$\begin{array}{llllll}6.3 & 12.0 & 1.9 & 5.3 & 1.2 & 3.3 \\ 5.5 & 10.6 & 1.8 & 3.8 & 1.1 & 2.5 \\ 4.1 & 7.9 & 1.2 & 2.8 & 0.7 & 1.7 \\ 4.1 & 7.8 & 0.9 & 2.0 & 0.5 & 1.3\end{array}$

Position in firm

$\begin{array}{llllll}4.4 & 8.8 & 0.9 & 3.8 & 0.3 & 2.3 \\ 5.2 & 12.2 & 0.9 & 4.2 & 0.4 & 3.0 \\ 7.2 & 12.7 & 2.3 & 5.4 & 1.6 & 3.6 \\ 2.0 & 5.7 & 0.4 & 2.1 & 0.2 & 1.3\end{array}$

Firm size

$\begin{array}{llllll}2.6 & 6.7 & 0.3 & 1.3 & 0.2 & 0.6 \\ 6.1 & 11.6 & 1.4 & 3.8 & 0.7 & 2.4 \\ 5.5 & 8.6 & 2.2 & 4.5 & 1.6 & 3.2\end{array}$

Firm ownership

$\begin{array}{llllll}0.7 & 4.5 & 0.1 & 1.2 & 0.1 & 0.8 \\ 5.9 & 9.8 & 1.4 & 3.1 & 1 & 2.3 \\ 6.1 & 20 & 2.9 & 14.6 & 1.3 & 9.7 \\ 3.6 & 9.2 & 1 & 3.7 & 0.4 & 1.7\end{array}$

Region

$\begin{array}{llllll}6.5 & 10.6 & 1.1 & 1.8 & 1.0 & 1.5 \\ 9.5 & 14.2 & 2.8 & 5.3 & 1.5 & 2.8\end{array}$


Table 5 Proportion of workers whose wage equals the minimum wage plus 10\%: comparisons to the basic wage and two measures of the total wage (Continued)

\begin{tabular}{|c|c|c|c|c|c|c|}
\hline Shandong & 0.6 & 4.2 & 0.3 & 1.9 & 0.3 & 1.4 \\
\hline Hubei & 4.6 & 10.0 & 0.3 & 1.4 & 0.1 & 0.6 \\
\hline Guangdong & 3.7 & 9.7 & 2.5 & 7.3 & 1.4 & 5.4 \\
\hline Shaanxi & 0.3 & 2.1 & 0.3 & 2.1 & 0.3 & 2.1 \\
\hline \multicolumn{7}{|c|}{ Ascending sort by firm revenue per worker } \\
\hline The first quintile & 6.2 & 11.3 & 1.9 & 5.3 & 1.5 & 4.3 \\
\hline The second quintile & 5.4 & 11.6 & 1.9 & 4.7 & 1.4 & 3.4 \\
\hline The third quintile & 3.9 & 8.7 & 1 & 3.1 & 0.8 & 2.1 \\
\hline The fourth quintile & 6.6 & 10 & 1.7 & 2.7 & 0.4 & 0.9 \\
\hline The fifth quintile & 2.4 & 5.7 & 0.3 & 1.2 & 0.2 & 0.6 \\
\hline \multicolumn{7}{|c|}{ Industry sectors } \\
\hline Apparel and textile products manufacturing & 12 & 19.5 & 3.8 & 6.6 & 2.9 & 4.8 \\
\hline $\begin{array}{l}\text { Communications equipment and computer } \\
\text { manufacturing other electronic equipment }\end{array}$ & 6.5 & 14 & 2.2 & 7.7 & 0.9 & 4.3 \\
\hline Other manufacturing & 3.7 & 8.5 & 1.1 & 2.8 & 0.5 & 1.6 \\
\hline Electricity, gas and water production & 0.7 & 3.3 & 0 & 1.1 & 0 & 0.2 \\
\hline Construction & 3.1 & 4.3 & 0.4 & 1 & 0.3 & 0.7 \\
\hline Transportation, storage and post & 5.3 & 6.5 & 1.4 & 2.4 & 1.3 & 1.9 \\
\hline Wholesale and retail trade (commerce) & 8.4 & 13.3 & 1.4 & 3.6 & 1.2 & 2.8 \\
\hline Financial service & 1.6 & 3.6 & 1.2 & 2.3 & 1.2 & 2.1 \\
\hline
\end{tabular}

Kernel density estimates of the distribution of the gap between the wage of each worker and the minimum wage (Fig. 1) are also consistent with the conclusion that employers consider minimum wages when setting the basic wage but that market wages are above the minimum wage for almost all workers. A value of zero in these figures indicates that the wage is equal to the minimum wage for these workers. There is a clear spike in the distribution of the basic wage at the level of the minimum wage and a censoring of the basic wage below the minimum, indicating that employers consider the minimum wage to be a wage floor when setting the regular monthly wage. However, the distributions of the total full-time wage (wage plus bonus and wage plus bonus plus supplements) appear to be only slightly affected by the minimum wage, with no clear spike at the minimum wage and only some censoring of the distribution below the minimum wage.

Women are more likely to earn the minimum wage than men (see Table 5). Younger, less skilled, less experienced, and less-educated workers are also more likely to earn the legal minimum. These low-skilled workers are likely to have low market wages. These are also the types of workers that we found are more likely to be paid below the minimum wage.

Workers in firms located in Guangdong province, in low revenue per worker (labor intensive) firms and in apparel, textile, and electronic equipment manufacturing are more likely to be earning the minimum wage. The category of firms with the highest 

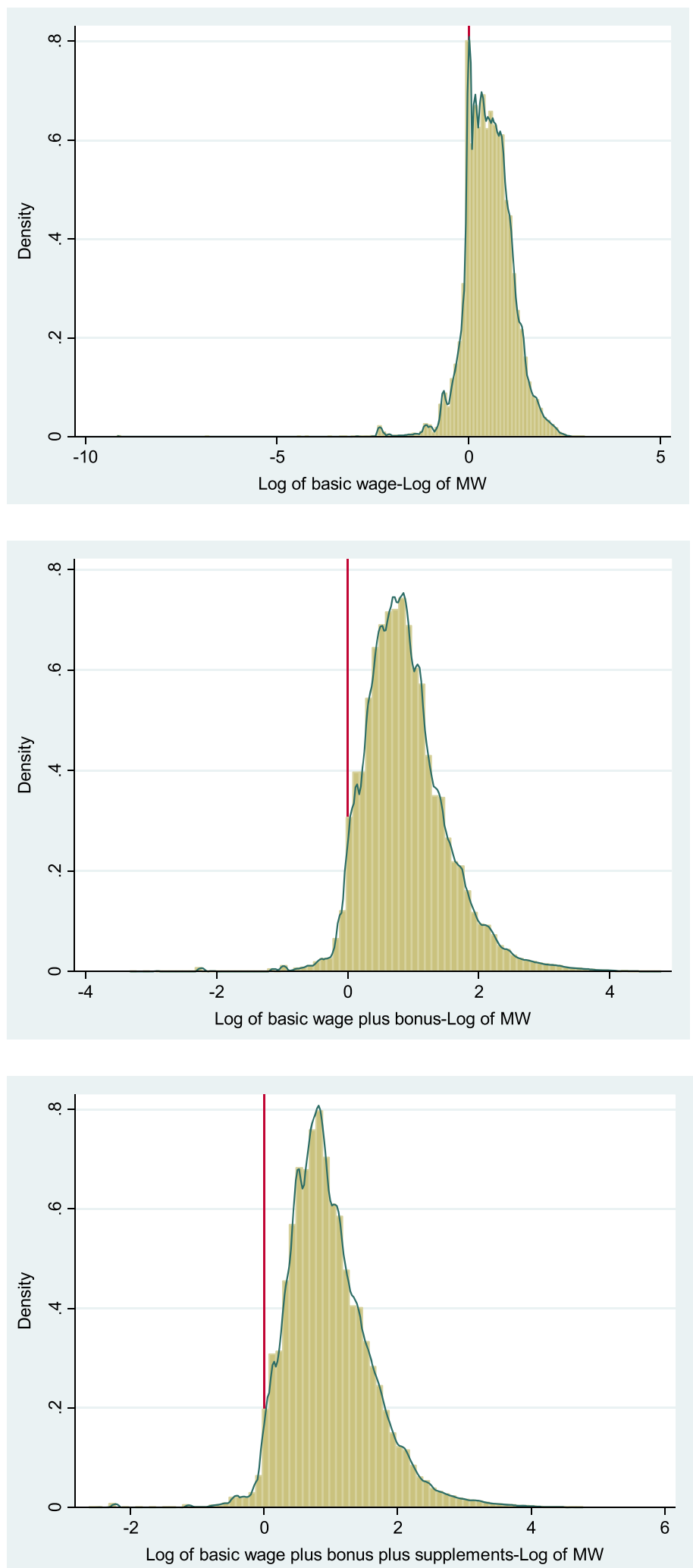

Fig. 1 For all workers: kernel density graphs for basic wage, basic wage plus bonus and total wage compared to minimum wage 
percentage of workers likely to be affected by minimum wages are those with owners from Taiwan, Macao, or Hong Kong. These firms tend to be, not surprisingly, labor intensive firms that manufacture apparel, textiles, and electronic equipment and are likely to depend heavily on exports.

However, even for groups that are likely to have low market wages, the percent of workers in our sample earning within $10 \%$ of the minimum wage is small. Using our upper bound of the estimates (the comparison with the basic wage plus the bonus), the highest proportion of workers earning within $10 \%$ of the minimum wage are for youngest workers (7.4\% for teenagers), those with a junior high school education or below (5.5\%), workers in Guangdong province (7.3\%), textile and apparel workers (6.6\%), electronics manufacturing workers $(7.7 \%)$, and workers in firms with the lowest revenue per worker. ${ }^{15}$ A very high percent of workers in firms with owners from Hong Kong, Macao, or Taiwan, almost 15\% using our upper-bound estimates, earn within 10\% of the minimum wage. However, these workers represent only $7.8 \%$ of our sample (see Table 1).

\subsection{Regression analysis comparing wages with the minimum wage}

To further explore the relationship between the different components of the wage and the minimum wage, we regress different components of the wage on the level of the minimum wage, controlling for personal characteristics, firm characteristics, and the regional characteristics. We are interested in discovering if the different types of wages for each worker are correlated with the level of the minimum wage in each local geographic region. We examine the impact of minimum wages on three types/components of the wage: (1) the basic wage, (2) the bonus, (3) the total full-time wage (basic wage plus bonus plus supplement). We also examine the impact of minimum wages on hours worked, which, because our data is for full-time workers only, will be an indicator of over-time hours. Personal characteristics that we control for include gender, age and age squared, experience and experience squared, a set of education dummy variables (high school, junior college and college or above, where the excluded category is junior high or below), and a set of occupational dummy variables. Firm characteristics that we control for include firm ownership dummies, firm size dummies, the revenue per worker, the labor cost to total expenditure ratio ${ }^{16}$, and the wage to other labor cost ratio. Regional characteristics that we control for are those that the minimum wage laws require local governments to consider when setting the minimum wage, and include an index of cost of living, average county-level wages, and the county GDP. Estimated errors are adjusted for clustering around firms. The results of these regressions are reported in Table 6 .

We find that there is a statistically significant positive correlation between the minimum wage and the basic wage. However, we find a statistically negative correlation between the minimum wage and bonus. For most workers, the higher basic wage and lower bonus cancel each other out so that we find that higher minimum wages are not significantly correlated with total full-time wages.

The coefficient on the $\log$ of minimum wages in the equation where the dependent variable is the log of basic wage is 0.9 , suggesting that a $1 \%$ increase 
Table 6 Wage regressions

\begin{tabular}{|c|c|c|c|c|}
\hline \multirow[b]{3}{*}{ Dependent variable } & \multicolumn{4}{|c|}{ Coefficients on each explanatory variable } \\
\hline & $(1)$ & $(2)$ & (3) & (4) \\
\hline & $\begin{array}{l}\text { Log of basic } \\
\text { monthly wage }\end{array}$ & $\begin{array}{l}\text { Log of } \\
\text { (bonus+1) }\end{array}$ & $\begin{array}{l}\text { Log of basic wage plus } \\
\text { bonus plus supplements }\end{array}$ & $\begin{array}{l}\text { Log of hours } \\
\text { worked }\end{array}$ \\
\hline \multirow[t]{2}{*}{ Log of minimum wage } & $0.872^{* * *}$ & $-6.299^{* * *}$ & -0.015 & 0.048 \\
\hline & $(0.212)$ & $(1.739)$ & $(0.111)$ & $(0.037)$ \\
\hline \multirow[t]{2}{*}{ Log of lowest living cost } & $-0.305^{*}$ & $3.881^{* * *}$ & 0.150 & -0.009 \\
\hline & $(0.170)$ & $(1.399)$ & $(0.092)$ & $(0.025)$ \\
\hline \multirow{2}{*}{$\begin{array}{l}\text { Log of county level average } \\
\text { wage }\end{array}$} & $0.280^{* * *}$ & $1.923^{* * *}$ & $0.519^{* * *}$ & -0.007 \\
\hline & $(0.070)$ & $(0.462)$ & $(0.043)$ & $(0.008)$ \\
\hline \multirow{2}{*}{$\begin{array}{l}\text { Log of county level GDP per } \\
\text { capita }\end{array}$} & 0.004 & 0.351 & $0.045^{*}$ & $-0.012^{*}$ \\
\hline & $(0.041)$ & $(0.379)$ & $(0.026)$ & $(0.006)$ \\
\hline \multirow[t]{2}{*}{ Female } & $-0.090^{* * *}$ & -0.117 & $-0.116^{* * *}$ & $-0.008^{* * *}$ \\
\hline & $(0.011)$ & $(0.079)$ & $(0.007)$ & $(0.002)$ \\
\hline \multirow[t]{2}{*}{ College or above } & $0.483^{* * *}$ & $0.735^{* * *}$ & $0.513^{* * *}$ & $-0.034^{* * *}$ \\
\hline & $(0.033)$ & $(0.212)$ & $(0.023)$ & $(0.004)$ \\
\hline \multirow[t]{2}{*}{ Junior college } & $0.213^{* * *}$ & $0.391^{* *}$ & $0.244^{* * *}$ & $-0.023^{* * *}$ \\
\hline & $(0.022)$ & $(0.171)$ & $(0.017)$ & $(0.004)$ \\
\hline \multirow[t]{2}{*}{ High school } & $0.050^{* * *}$ & 0.126 & $0.083^{* * *}$ & $-0.009^{* *}$ \\
\hline & $(0.018)$ & $(0.148)$ & $(0.012)$ & $(0.004)$ \\
\hline \multirow[t]{2}{*}{ Age } & $0.021^{* * *}$ & 0.031 & $0.024^{* * *}$ & -0.001 \\
\hline & $(0.006)$ & $(0.038)$ & $(0.005)$ & $(0.001)$ \\
\hline \multirow[t]{2}{*}{ Age squared } & $-0.000^{* * *}$ & -0.000 & $-0.000^{* * *}$ & 0.000 \\
\hline & $(0.000)$ & $(0.001)$ & $(0.000)$ & $(0.000)$ \\
\hline \multirow[t]{2}{*}{ Experience } & $0.012^{* * *}$ & 0.018 & $0.011^{* * *}$ & $-0.002^{* *}$ \\
\hline & $(0.004)$ & $(0.028)$ & $(0.003)$ & $(0.001)$ \\
\hline \multirow[t]{2}{*}{ Experience squared } & $-0.000^{* * *}$ & -0.000 & $-0.000^{* * *}$ & $0.000^{*}$ \\
\hline & $(0.000)$ & $(0.001)$ & $(0.000)$ & $(0.000)$ \\
\hline \multirow[t]{2}{*}{ State funded firm } & -0.080 & 0.656 & 0.016 & 0.005 \\
\hline & $(0.059)$ & $(0.506)$ & $(0.043)$ & $(0.008)$ \\
\hline \multirow{2}{*}{$\begin{array}{l}\text { HongKong, Taiwan, Macao } \\
\text { funded firm }\end{array}$} & $0.120^{* *}$ & -0.717 & 0.022 & $0.051^{* * *}$ \\
\hline & $(0.054)$ & $(0.490)$ & $(0.035)$ & $(0.013)$ \\
\hline \multirow[t]{2}{*}{ Foreign funded firm } & $0.228^{* * *}$ & 0.298 & $0.131^{* * *}$ & $0.025^{* * *}$ \\
\hline & $(0.059)$ & $(0.510)$ & $(0.033)$ & $(0.009)$ \\
\hline \multirow[t]{2}{*}{ Large size firm } & $-0.094^{*}$ & $1.611^{* * *}$ & $0.097^{* * *}$ & $-0.016^{* *}$ \\
\hline & $(0.052)$ & $(0.465)$ & $(0.032)$ & $(0.008)$ \\
\hline \multirow[t]{2}{*}{ Medium size firm } & -0.022 & $0.513^{*}$ & $0.060^{* * *}$ & 0.001 \\
\hline & $(0.031)$ & $(0.264)$ & $(0.019)$ & $(0.006)$ \\
\hline \multirow[t]{2}{*}{ Log of firm revenue per worker } & $0.077^{* * *}$ & $0.323^{* *}$ & $0.096^{* * *}$ & 0.002 \\
\hline & $(0.015)$ & $(0.127)$ & $(0.011)$ & $(0.003)$ \\
\hline \multirow{3}{*}{$\begin{array}{l}\text { Proportion of labor cost to total } \\
\text { expenditure }\end{array}$} & $0.250^{* * *}$ & -0.563 & $0.234^{* * *}$ & -0.021 \\
\hline & $(0.096)$ & $(0.774)$ & $(0.061)$ & $(0.014)$ \\
\hline & -0.096 & $1.353^{* *}$ & -0.054 & $-0.045^{* * *}$ \\
\hline
\end{tabular}


Table 6 Wage regressions (Continued)

\begin{tabular}{lllll}
\hline $\begin{array}{l}\text { Other labor cost to wage } \\
\text { expenditure }\end{array}$ & \multicolumn{1}{l}{ (0.069) } & $(0.573)$ & $(0.042)$ & \\
& YES & YES & YES & $(0.011)$ \\
Dummies for position in firm & YES & YES & YES & YES \\
Dummies for sectors & 514497 & 521501 & 521074 & YES \\
Observations & 0.350 & 0.228 & 0.556 & 521501 \\
$R^{2}$ & & & & 0.139 \\
\hline
\end{tabular}

Standard errors in parentheses

${ }^{*} p<0.1,{ }^{* *} p<0.05,{ }^{* * *} p<0.01$

in the minimum wage is associated with an approximately $0.9 \%$ increase in the basic wage. The coefficient in the bonus equation is a -6.3 , suggesting that a $1 \%$ increase in the minimum wage leads to an approximately $6 \%$ drop in bonus payments. Because bonuses are only $20 \%$ of earnings while the basic wage is $60 \%$, a $1 \%$ change in the basic wage is a much bigger absolute increase than a $1 \%$ change in the bonus. This can easily be seen if we assume that the total wage is 100 (so that the basic wage is 60 and the bonus is 20). In this case, our results from Table 6 predict that a $1 \%$ increase in the minimum wage would lead to an increase in the basic wage of approximately $0.54(0.9 \%$ of 60$)$ and a drop in the bonus by 1.2 (6\% of 20 ).

Because we have data on firms at only one point in time, we can only examine correlations across regions. It is possible that our regressions are not capturing the causal effect of minimum wages on wages, but instead are capturing the effect of local labor market conditions on both minimum wages and the actual wages paid to workers. We try to control for this by including indicators of local labor market conditions as control variables, but we may not have data on all the factors that affect the setting of minimum wages and actual wages. However, if both the minimum wage and actual wages move in the same direction because of local labor market conditions, then both bonuses and basic wages should be positively correlated with minimum wages. Contrary to this expectation, we find that bonuses are negatively correlated with minimum wages across regions. This suggests that our regression results are not due to omitted variables relating to economic conditions in each region.

While we find that total full-time wages are not correlated with minimum wages for workers in general, it is possible that there is a correlation for some sub-sets of workers. For example, we found earlier in the paper that the proportion of workers earning at or below the minimum wage is higher for women compared to men, for less-skilled and less-educated workers, for younger and less-experienced workers, for workers in firms with low revenue per worker (labor-intensive firms), for firms whose owners are from Hong Kong, Taiwan, or Macao, and for firms in Guangdong province. Controlling for personal, firm, and regional characteristics, we examine whether minimum wages are statistically significantly correlated with wages for these sub-groups. The regression results for different sub-groups of workers are presented in Table 7. 
Table 7 Wage regression results: coefficients on the log of the minimum wage for different groups of workers

\begin{tabular}{|c|c|c|c|c|}
\hline \multicolumn{5}{|c|}{ Coefficients on the minimum wage variable only } \\
\hline & (1) & $(2)$ & (3) & (4) \\
\hline Dependent variable & $\begin{array}{l}\text { Log of basic monthly } \\
\text { wage }\end{array}$ & $\begin{array}{l}\text { Log of } \\
\text { (bonus+1) }\end{array}$ & $\begin{array}{l}\text { Log of basic wage } \\
\text { plus bonus plus } \\
\text { supplements }\end{array}$ & $\begin{array}{l}\text { Log of hours } \\
\text { worked }\end{array}$ \\
\hline \multicolumn{5}{|l|}{ Gender } \\
\hline \multirow[t]{2}{*}{ Male } & $1.008^{* * *}$ & $-5.386^{* * *}$ & 0.095 & 0.052 \\
\hline & $(0.228)$ & $(1.748)$ & $(0.119)$ & $(0.037)$ \\
\hline \multirow[t]{2}{*}{ Female } & $0.746^{* * *}$ & $-7.792^{* * *}$ & -0.143 & 0.046 \\
\hline & $(0.224)$ & $(1.928)$ & $(0.119)$ & $(0.041)$ \\
\hline \multicolumn{5}{|l|}{ Educational attainment } \\
\hline \multirow[t]{2}{*}{ College or above } & $0.640^{* *}$ & $-10.684^{* * *}$ & -0.410 & $0.068^{*}$ \\
\hline & $(0.305)$ & $(3.232)$ & $(0.325)$ & $(0.041)$ \\
\hline \multirow[t]{2}{*}{ Junior college } & $1.177^{* * *}$ & $-8.171^{* * *}$ & 0.142 & 0.013 \\
\hline & $(0.264)$ & $(1.979)$ & $(0.180)$ & $(0.040)$ \\
\hline \multirow[t]{2}{*}{ High school } & $1.081^{* * *}$ & $-6.191^{* * *}$ & 0.177 & 0.014 \\
\hline & $(0.238)$ & $(1.833)$ & $(0.109)$ & $(0.036)$ \\
\hline \multirow{2}{*}{$\begin{array}{l}\text { Junior high school } \\
\text { or below }\end{array}$} & $0.836^{* * *}$ & $-5.204^{* * *}$ & -0.014 & 0.081 \\
\hline & $(0.206)$ & $(2.000)$ & $(0.121)$ & $(0.052)$ \\
\hline \multicolumn{5}{|l|}{ Age cohort } \\
\hline \multirow[t]{2}{*}{ Age $16-20$} & $1.134^{* * *}$ & $-9.679^{* * *}$ & -0.122 & 0.094 \\
\hline & $(0.349)$ & $(2.408)$ & $(0.163)$ & $(0.073)$ \\
\hline \multirow[t]{2}{*}{ Age $21-25$} & $1.029^{* * *}$ & $-9.606^{* * *}$ & -0.014 & 0.075 \\
\hline & $(0.290)$ & $(2.013)$ & $(0.127)$ & $(0.051)$ \\
\hline \multirow[t]{2}{*}{ Age 26-30 } & $0.791^{* * *}$ & $-7.723^{* * *}$ & -0.071 & $0.073^{*}$ \\
\hline & $(0.234)$ & $(1.777)$ & $(0.127)$ & $(0.039)$ \\
\hline \multirow[t]{2}{*}{ Age $31+$} & $0.834^{* * *}$ & $-5.093^{* * *}$ & 0.026 & 0.031 \\
\hline & $(0.206)$ & $(1.787)$ & (0.119) & $(0.035)$ \\
\hline \multicolumn{5}{|l|}{ Experience cohort } \\
\hline \multirow[t]{2}{*}{ Experience 1-3 } & $0.984^{* * *}$ & $-10.118^{* * *}$ & -0.091 & 0.083 \\
\hline & $(0.251)$ & $(1.856)$ & $(0.144)$ & $(0.058)$ \\
\hline \multirow[t]{2}{*}{ Experience 4-6 } & 0.403 & $-5.396^{* * *}$ & -0.169 & 0.070 \\
\hline & $(0.269)$ & $(1.854)$ & $(0.149)$ & $(0.048)$ \\
\hline \multirow[t]{2}{*}{ Experience 7-9 } & $0.634^{* * *}$ & $-7.599 * * *$ & -0.032 & $0.086^{* *}$ \\
\hline & $(0.229)$ & $(2.042)$ & $(0.131)$ & $(0.034)$ \\
\hline \multirow[t]{2}{*}{ Experience $10+$} & $0.964^{* * *}$ & $-4.547^{* *}$ & 0.109 & -0.011 \\
\hline & $(0.242)$ & $(2.091)$ & $(0.132)$ & $(0.036)$ \\
\hline \multicolumn{5}{|l|}{ Position in firm } \\
\hline \multirow[t]{2}{*}{ Office workers } & $1.133^{* * *}$ & $-10.192^{* * *}$ & -0.046 & -0.020 \\
\hline & $(0.366)$ & (2.014) & $(0.251)$ & $(0.040)$ \\
\hline \multirow{2}{*}{$\begin{array}{l}\text { Manual workers with } \\
\text { no skill certificate }\end{array}$} & $0.649^{* * *}$ & $-6.852^{* * *}$ & -0.032 & $0.139 * * *$ \\
\hline & $(0.233)$ & $(2.100)$ & $(0.134)$ & $(0.050)$ \\
\hline
\end{tabular}


Table 7 Wage regression results: coefficients on the log of the minimum wage for different groups of workers (Continued)

\begin{tabular}{|c|c|c|c|c|}
\hline \multicolumn{5}{|l|}{ Firm ownership } \\
\hline \multirow[t]{2}{*}{ State funded firm } & $1.141^{*}$ & $-8.059^{* *}$ & 0.456 & 0.010 \\
\hline & $(0.668)$ & $(3.721)$ & $(0.454)$ & $(0.119)$ \\
\hline \multirow{2}{*}{$\begin{array}{l}\text { Non-state domestic funded } \\
\text { firm }\end{array}$} & $0.998^{* * *}$ & $-4.502^{* *}$ & 0.074 & 0.041 \\
\hline & $(0.237)$ & $(2.152)$ & $(0.124)$ & $(0.044)$ \\
\hline \multirow{2}{*}{$\begin{array}{l}\text { HongKong, Taiwan, Macao } \\
\text { funded firm }\end{array}$} & 0.398 & $-19.374^{* * *}$ & -0.198 & 0.243 \\
\hline & $(0.462)$ & $(5.027)$ & $(0.379)$ & $(0.177)$ \\
\hline \multirow[t]{2}{*}{ Foreign funded firm } & $1.185^{*}$ & $-9.291^{* * *}$ & 0.555 & -0.032 \\
\hline & $(0.625)$ & (3.079) & $(0.453)$ & $(0.124)$ \\
\hline \multicolumn{5}{|l|}{ Firm size } \\
\hline \multirow[t]{2}{*}{ Large } & 0.796 & -5.563 & 0.393 & 0.038 \\
\hline & $(0.773)$ & $(5.963)$ & $(0.404)$ & $(0.083)$ \\
\hline \multirow[t]{2}{*}{ Medium } & $0.702^{* *}$ & $-5.769^{* * *}$ & 0.003 & 0.039 \\
\hline & $(0.283)$ & $(2.185)$ & $(0.161)$ & $(0.060)$ \\
\hline \multirow[t]{2}{*}{ Small } & $0.486^{* *}$ & -1.597 & 0.165 & $0.119^{* *}$ \\
\hline & $(0.204)$ & $(1.688)$ & $(0.145)$ & $(0.048)$ \\
\hline \multicolumn{5}{|c|}{ Labor intensive firms: ascending sort by firm revenue per worker } \\
\hline \multirow[t]{2}{*}{ The first quintile } & $1.221^{* * *}$ & -2.924 & $0.907^{* * *}$ & $0.127^{*}$ \\
\hline & $(0.229)$ & $(2.594)$ & $(0.206)$ & $(0.073)$ \\
\hline \multirow[t]{2}{*}{ The second quintile } & 0.222 & -4.986 & 0.115 & 0.006 \\
\hline & $(0.424)$ & $(3.522)$ & $(0.274)$ & $(0.064)$ \\
\hline \multirow[t]{2}{*}{ The third quintile } & 0.674 & $-4.517^{*}$ & $-0.279^{*}$ & -0.033 \\
\hline & $(0.410)$ & $(2.617)$ & $(0.163)$ & $(0.086)$ \\
\hline \multirow[t]{2}{*}{ The fourth quintile } & 0.615 & $-10.761^{* * *}$ & -0.267 & $0.208^{* * *}$ \\
\hline & $(0.387)$ & (3.338) & $(0.220)$ & $(0.060)$ \\
\hline \multirow[t]{2}{*}{ The fifth quintile } & $1.114^{* * *}$ & $-6.757^{* *}$ & 0.157 & $0.074^{*}$ \\
\hline & $(0.395)$ & $(2.715)$ & $(0.287)$ & $(0.041)$ \\
\hline
\end{tabular}

Standard errors in parentheses

${ }^{*} p<0.1,{ }^{* *} p<0.05,{ }^{* * *} p<0.01$

For all sub-groups of workers, we find that higher minimum wages are significantly positively correlated with the basic wage but negatively correlated with the bonus. For most sub-groups of workers, the higher basic wage and lower bonus cancel each other out, and the minimum wage is not significantly correlated with the total wage. However, there are some types of workers for whom higher minimum wages are significantly correlated with higher total wages. These are workers in the most labor-intensive (with the lowest revenue per worker) firms. We do not find a significant correlation between minimum wages and total wages for any other sub-group of workers, only for workers in the most labor-intensive firms.

We have noted that most workers who work overtime hours do not receive the legally-mandated $150 \%$ of their regular pay for overtime work and that close to $29 \%$ receive no pay at all for overtime hours. This suggests that if employers are 
faced with higher costs because of higher minimum wages, they may compensate by increasing over-time hours. As we have shown that higher minimum wages are likely to affect only the least-skilled workers in the most labor-intensive firms, we would expect any hours worked effect of minimum wages to be primarily among these workers. We examine this possibility by replacing the log of wage with the $\log$ of hours worked as the dependent variable in the regressions. The results are presented in the fourth column of Tables 6 and 7. For almost all subsets of workers, higher minimum wages are positively correlated with higher hours worked, although for most subsets of workers this correlation is not statistically significant. Minimum wages are significantly correlated with greater hours worked for the workers we identified as most likely to earn near the minimum wage, the least skilled workers (i.e., manual workers with no skills) in the most labor-intensive firms. ${ }^{17}$

\section{Conclusions}

In this paper we use matched firm-employee data on over 500,000 workers to examine whether firms comply with legal minimum wages and other pay regulations in China. We find evidence that there is broad compliance with minimum wages in China in that very few full-time workers earn less than the monthly minimum wage. Specifically, we estimate that fewer than 3.5\% of full-time workers in China earn less than the monthly minimum wage compared to $20-45 \%$ of workers that published studies report earn less than the legal minimum wage in many other developing economies.

Despite widespread compliance with monthly legal minimum wages, we present evidence that few workers are likely to see their total wages change when minimum wages increase. This is because the minimum wage is below the market wage for almost all of the Chinese workers in our sample. Workers in formal sector firms in China are paid a "basic wage" plus supplements for transportation, risk, etc., plus a bonus related to productivity. All workers with the same position in the same firm (who do the same job) receive the same basic wage, which is determined prior to performing the work. Bonuses, on the other hand, depend on performance, may differ between workers in the same position in the firm, and are not determined until after the work is performed. Minimum wages appear to be taken into consideration by many firms when setting the basic wage. We find that basic wages are set at exactly the minimum wage for a relatively large fraction of workers. However, once bonuses and supplements are taken into account, almost all workers earn more than the minimum wage. We also find that there is a positive correlation between the minimum wage and the basic wage. On the other hand, we find that there is a negative correlation between the minimum wage and the bonus. For most workers, the higher basic wage and lower bonus cancel each other out and the minimum wage is not significantly correlated with the total wage. Only for workers in the most labor-intensive firms and low profit/revenue firms are higher minimum wages significantly correlated with higher total wages. These firms, where workers are most likely to be affected by legal minimum wages, are disproportionately export-oriented firms located in the more developed eastern Chinese provinces such as Guangdong. 
While most full-time workers are paid more than the legal monthly minimum wage, many workers are not paid the legally-mandated minimum for overtime hours. Specifically, we find that over $29 \%$ of the workers in our sample who work more than $40 \mathrm{~h}$ per week are paid nothing for the additional hours of work. Of those who are paid, most are not paid legally-mandated overtime pay; over $40 \%$ of the employees who work overtime are paid less than 1.5 times the legal minimum wage for these hours of overtime work, and almost $70 \%$ are paid less than the legally-mandated 1.5 times regular pay. Since $41 \%$ of workers in our sample work more than $40 \mathrm{~h}$ per week, this implies that formal sector firms in China do not pay legally-mandated overtime pay to over $26 \%$ of all employees. All types of firms, including state-owned firms, are likely to violate overtime pay laws.

Lack of compliance with overtime pay regulations suggests that if employers are faced with higher costs because of higher minimum wages, then they may compensate by requiring workers to work more hours. We examine this possibility by regressing hours worked on the minimum wage. We find that higher minimum wages are significantly correlated with greater hours worked for workers in the most labor-intensive firms and for the least skilled workers.

The literature on the labor market impacts of minimum wages in China reports small and non-robust negative wage and employment effects. The results presented in this paper help to explain why the impact of minimum wages is small in China despite widespread compliance with minimum wage laws. First, we present evidence that the impact of minimum wages on the wages paid to workers depends on the wage considered. Specifically, we present evidence that minimum wages are correlated with basic wages but that most workers in China are paid performance-based bonuses that cause the total full-time monthly wage of workers to be above the legal minimum wage. When minimum wages increase, our results suggest that firms increase the basic wage but lower bonuses so that total full-time wages stay the same. Second, we find that the minimum wage does affect the wages of some workers, specifically the lowest-skilled workers in the most labor-intensive firms. However, our results suggest that for these workers firms adjust to the higher labor costs not by reducing the level of employment, but by increasing hours worked.

Our results also have implications for attempts to improve the earnings of lowwage workers in China through increased compliance with labor protection regulations. Specifically, the focus of inspectors and others should be on improving compliance with over-time pay regulations as well as compliance with legal minimum wages.

\section{Endnotes}

${ }^{1}$ What should be included in minimum wage paid to workers may also be different in different provinces. For example, minimum wages in Beijing, Shanghai, and Jiangxi provinces do not include the employee payments to social security or housing provident funds. In China, social security payments and housing provident funds are co-paid by employee and employer. The employer portion of social security payments and housing provident funds are excluded from the wage 
calculation in all provinces. Minimum wages in Jiangsu province include social security payments by the employee but not housing provident funds.

${ }^{2}$ The structural hierarchy of the administrative divisions of the People's Republic of China is as follows: Provincial level, Prefectural City level, County level. Currently, Chinese mainland administers 33 provincial level regions, 333 prefectural level regions, 2,862 county-level regions.

${ }^{3}$ The highest monthly minimum wage level is 1000 yuan, the lowest monthly minimum wage level is 390 yuan, and the mean monthly minimum wage level is 642 yuan. On November 17, 2008 the Department of Human Resources and Social Securities instructed local governments to restrain from increasing minimum wages in 2009 as a way to ease the negative influence of an international financial crisis. This implies that the minimum wage enforced in 2009 was set in 2008 or 2007.

${ }^{4}$ For example, Article 85 of the Labor Contract Law of the People's Republic of China, adopted in 2007, states "The labor administration authority... shall order the employer to pay labor remunerations if overtime pay or economic compensation is not provided within the prescribed period of time. Where the standard of labor remuneration is lower than the local minimum wage rate the employer shall be ordered to make up the balance. When due payment is not made within the time limit, the employer shall be ordered to pay additional damages to the employee" (authors' translation).

${ }^{5}$ Not all violations of labor regulations are treated as leniently. For example, fines are imposed on firms if it is found that they have hired children under 16 years old.

${ }^{6}$ Our summary of the behavior of labor inspections in practice is derived from interviews with former and current labor department officials and academics who study labor law. Those interviewed included Hainan Su, a Beijing Normal University professor and former official of the Ministry of Human Resources and Social Security, Chengbao $\mathrm{Xu}$, an official in the Nanjing Human Resources and Social Security Department and Jianguo Qin, associate professor of finance and economics at the Nanjing University of Economics and Finance.

${ }^{7}$ The source of the information in this paragraph is Hainan $\mathrm{Su}$, a Beijing Normal University professor and former official of the Ministry of Human Resources and Social Security and Chengbao $\mathrm{Xu}$, an official in the Nanjing Human Resources and Social Security Department.

${ }^{8}$ For example, Article 85, Article 90, and Article 91. Article 91 states that "when an employing unit infringes on any of the following legitimate rights and interests of laborers, the labor administrative department shall order it to pay laborers remuneration or to make up for economic losses" if firms do the following: "(1) deduct wages or delay paying wages to laborers without reason, (2) refuse to pay laborers for extended working hours, to pay laborers wages below the local standard on minimum wages, or to fail to provide laborers with economic compensations in accordance with the provisions of this law after revocation of labor contracts" (authors' translation).

${ }^{9}$ The term "rural migrant" in China refers to workers whose legal residence (citizenship or "hukou") is in rural areas but who are temporary migrants to urban areas. Under the "hukou" (household registration) system, social services, such as 
government-subsidized health care, education, and pension, are available to workers only in their legal residence. Rural migrants generally return to their legal residence in rural areas to access these services, for holidays, and when they leave their jobs in urban areas. It is difficult to change your legal residence. Rural migrants tend to earn less than citizens of urban areas, and one key motivation for the introduction of legal minimum wages was to protect rural migrant workers.

${ }^{10}$ The capital city of the province is always the most developed city in this province in China.

${ }^{11}$ Table 9 in the appendix presents descriptive statistics for the data we use. Table 10 compares summary statistics from our sample to summary statistics from the 2008 National Economic Census of China. These comparisons show that the distributions of workers by gender and education level are similar for our sample and the census. Our sample includes slightly fewer workers with a college and junior high school education compared to the census, and slightly more with a high school education. Compared to the census, our sample includes slightly more workers in manufacturing firms (66\% vs. 63\%), electricity gas and water production (5\% vs. $1.5 \%)$ and transportation, storage and post (7\% vs. $5 \%$ ), and fewer workers in construction $(8.5 \%$ vs. $18 \%)$. Our sample also includes more stateowned and foreign-owned firms and fewer non-state domestically owned firms. In the body of the paper, we always report our results separately for different genders and education levels and for firms of different ownership types and different industry sectors.

${ }^{12}$ Unfortunately, we cannot identify rural migrants in our data, nor do we have data on the exports of firms.

${ }^{13}$ Labor regulations in Beijing and Jiangsu provinces mandate excluding additional supplements when comparing the wage to the minimum wage. Taking these special rules into account does not change our results dramatically. For example, when we adjust the wage and minimum wage for the regulations specific to these two provinces, the proportion of workers earning less than the minimum wage increases from 1.3 to $3.7 \%$ in Beijing and from 1.5 to $3.6 \%$ in Jiangsu (see Table 8).

${ }^{14}$ This may also help explain why foreign-owned firms are more likely to violate minimum wage laws and more likely to pay for overtime.

${ }^{15}$ Particularly striking is that $12 \%$ of workers in apparel and textile manufacturing have basic wages equal to exactly the minimum wage, although half of these worker earn bonuses and supplements that cause total wages to be above the minimum.

${ }^{16} \mathrm{We}$ include revenue per worker as an indicator of the labor intensity of the firm, while we include both labor cost to total expenditure, we do not believe that this is a good indicator of the labor intensity of the firm. This is because many labor intensive firms are export-oriented electronic assembly or apparel firms where the cost of the imported parts to be assembled are a large part of firm expenditures. Therefore, even though these assembly firms are labor intensive, the labor cost to total expenditure is low.

${ }^{17}$ This result is consistent with the finding in Yang et al. (2014) that higher minimum wages for rural migrants lead to higher total monthly earnings and hours worked but lower hourly wages. Interestingly, we also find that higher minimum wages are 


\section{Appendix}

Table 8 Beijing and Jiangsu: Percent of workers whose monthly wage is below not adjusted and adjusted monthly legal minimum wage

\begin{tabular}{|c|c|c|c|c|}
\hline & \multicolumn{2}{|c|}{$\begin{array}{l}\text { Basic wage }+ \text { bonus is } \\
\text { below the MW }\end{array}$} & \multicolumn{2}{|c|}{$\begin{array}{l}\text { Basic wage }+ \text { bonus }+ \\
\text { supplements is below } \\
\text { MW }\end{array}$} \\
\hline & Not adjusted & Adjusted $^{\mathrm{a}}$ & Not adjusted & Adjusted $^{a}$ \\
\hline All & 1.8 & 6.0 & 1.1 & 3.7 \\
\hline \multicolumn{5}{|l|}{ Gender } \\
\hline Male & 1.5 & 4.6 & 1.0 & 3.0 \\
\hline Female & 2.2 & 8.1 & 1.3 & 4.6 \\
\hline \multicolumn{5}{|l|}{ Educational attainment } \\
\hline College or above & 0.6 & 1.2 & 0.5 & 0.7 \\
\hline Junior college & 1.3 & 2.5 & 0.7 & 1.4 \\
\hline High school & 1.8 & 5.6 & 1.1 & 3.4 \\
\hline Junior high school or below & 2.5 & 10.0 & 1.6 & 6.2 \\
\hline \multicolumn{5}{|l|}{ Age cohort } \\
\hline Age 16-20 & 3.7 & 11.9 & 2.8 & 8.2 \\
\hline Age $21-25$ & 2.5 & 6.4 & 1.5 & 3.5 \\
\hline Age $26-30$ & 1.7 & 5.2 & 1.1 & 2.8 \\
\hline Age $31+$ & 1.5 & 5.7 & 0.9 & 3.6 \\
\hline \multicolumn{5}{|l|}{ Experience cohort } \\
\hline Experience 1-3 & 3.3 & 9.8 & 2.3 & 6.3 \\
\hline Experience 4-6 & 1.7 & 6.9 & 1.0 & 3.8 \\
\hline Experience 7-9 & 1.3 & 5.1 & 0.6 & 2.7 \\
\hline Experience $10+$ & 1.0 & 3.5 & 0.6 & 2.2 \\
\hline \multicolumn{5}{|l|}{ Position in firm } \\
\hline Manual work & 4.6 & 6.9 & 3.4 & 4.6 \\
\hline Worker with junior skill certificate & 0.6 & 3.3 & 0.4 & 1.5 \\
\hline Worker with no skill certificate & 2.2 & 9.5 & 1.3 & 5.9 \\
\hline Others & 0.8 & 2.1 & 0.4 & 1.1 \\
\hline \multicolumn{5}{|l|}{ Firm ownership } \\
\hline State funded firm & 1.1 & 1.6 & 0.0 & 0.4 \\
\hline Non-state domestic funded firm & 2.2 & 6.7 & 1.4 & 4.6 \\
\hline HongKong, Taiwan, Macao funded firm & 1.0 & 8.1 & 0.5 & 2.3 \\
\hline Foreign funded firm & 1.4 & 4.8 & 1.1 & 2.8 \\
\hline \multicolumn{5}{|l|}{ Firm size } \\
\hline Large & 1.4 & 3.0 & 1.1 & 1.5 \\
\hline Medium & 2.0 & 7.0 & 1.1 & 4.1 \\
\hline Small & 1.8 & 7.0 & 1.2 & 4.8 \\
\hline \multicolumn{5}{|c|}{ Labor intensive firms: ascending sort by firm revenue per worker } \\
\hline The first quintile & 5.9 & 13.8 & 4.1 & 9.1 \\
\hline The second quintile & 3.3 & 10.2 & 2.6 & 7.6 \\
\hline The third quintile & 1.4 & 6.4 & 0.8 & 3.9 \\
\hline The fourth quintile & 0.6 & 3.9 & 0.2 & 1.4 \\
\hline The fifth quintile & 1.0 & 2.4 & 0.5 & 1.3 \\
\hline
\end{tabular}


Table 8 Beijing and Jiangsu: Percent of workers whose monthly wage is below not adjusted and adjusted monthly legal minimum wage (Continued)

\begin{tabular}{lllll}
\hline Industry sectors & & & & \\
Apparel and textile products manufacturing & 1.4 & 8.8 & 1.3 & 6.1 \\
Communications equipment, computer manufacturing & 2.6 & 7.5 & 1.8 & 5.7 \\
Other manufacturing & 1.3 & 5.7 & 0.7 & 2.8 \\
Electricity, gas and water production & 0.0 & 0.0 & 0.0 & 0.0 \\
Construction & 1.3 & 2.9 & 0.6 & 1.6 \\
Transportation, storage and post & 4.9 & 9.1 & 4.0 & 7.2 \\
Wholesale and retail trade(commerce) & 2.5 & 6.0 & 1.1 & 4.1 \\
Financial service & 0.3 & 0.3 & 0.1 & 0.1
\end{tabular}

${ }^{a}$ In Beijing, adjusted wages exclude the employee contribution to social insurance and housing provision funds. In Jiangsu, adjusted wages exclude only housing provision funds 
Table 9 Descriptive statistics

\begin{tabular}{|c|c|c|c|c|}
\hline Variables & Number of obs & Mean & Min & Max \\
\hline \multicolumn{5}{|l|}{ Personal level variables } \\
\hline \multicolumn{5}{|l|}{ Wages } \\
\hline Mean monthly total wage (yuan) & 521501 & 2657 & 320 & 82000 \\
\hline Mean monthly basic wage (yuan) & 521501 & 1592 & 0 & 82000 \\
\hline Mean monthly bonus (yuan) & 521501 & 682 & 0 & 75438 \\
\hline Mean monthly supplements (yuan) & 521501 & 199 & 0 & 67035 \\
\hline Mean monthly overtime pay (yuan) & 521501 & 185 & 0 & 29042 \\
\hline \multicolumn{5}{|l|}{ Gender } \\
\hline Proportion female & 521501 & 0.395 & 0 & 1 \\
\hline \multicolumn{5}{|l|}{ Educational attainment (proportion or workers at each level) } \\
\hline College or above & 521501 & 0.109 & 0 & 1 \\
\hline Junior college & 521501 & 0.164 & 0 & 1 \\
\hline High school & 521501 & 0.420 & 0 & 1 \\
\hline Junior high school or below & 521501 & 0.306 & 0 & 1 \\
\hline Age (mean) & 521501 & 34 & 16 & 65 \\
\hline Experience (mean) & 521501 & 12 & 1 & 50 \\
\hline \multicolumn{5}{|l|}{ Position in firm (proportion of workers at each level) } \\
\hline Office work & 521501 & 0.103 & 0 & 1 \\
\hline Manual worker with junior skill certificate & 521501 & 0.141 & 0 & 1 \\
\hline Manual worker with no skill certificate & 521501 & 0.402 & 0 & 1 \\
\hline Others & 521501 & 0.354 & 0 & 1 \\
\hline \multicolumn{5}{|l|}{ Industry sectors } \\
\hline Apparel and textile products manufacturing & 521501 & 0.082 & 0 & 1 \\
\hline Communications equipment, computer manufacturing & 521501 & 0.069 & 0 & 1 \\
\hline Other manufacturing & 521501 & 0.508 & 0 & 1 \\
\hline Electricity, gas and water production & 521501 & 0.051 & 0 & 1 \\
\hline Construction & 521501 & 0.085 & 0 & 1 \\
\hline Transportation, storage and post & 521501 & 0.073 & 0 & 1 \\
\hline Wholesale and retail trade(commerce) & 521501 & 0.106 & 0 & 1 \\
\hline Financial service & 521501 & 0.026 & 0 & 1 \\
\hline \multicolumn{5}{|l|}{ Firm level variables } \\
\hline Mean yearly average number of employees & 2835 & 361 & 1 & 41500 \\
\hline \multicolumn{5}{|l|}{ Firm ownership (proportion of firms) } \\
\hline State funded firm & 2835 & 0.095 & 0 & 1 \\
\hline Non-state domestic funded firm & 2835 & 0.708 & 0 & 1 \\
\hline HongKong, Taiwan, Macao funded firm & 2835 & 0.075 & 0 & 1 \\
\hline Foreign funded firm & 2835 & 0.122 & 0 & 1 \\
\hline \multicolumn{5}{|l|}{ Firm size (proportion of firms) } \\
\hline Large & 2835 & 0.057 & 0 & 1 \\
\hline Medium & 2835 & 0.230 & 0 & 1 \\
\hline Small & 2835 & 0.713 & 0 & 1 \\
\hline Firm revenue per worker (mean)(unit:10,000yuan) & 2835 & 114.98 & 0.02 & 12649 \\
\hline Proportion of labor cost to total expenditure (mean) & 2835 & 0.224 & 0 & 1 \\
\hline Other labor cost to wage expenditure (mean) & 2835 & 0.415 & 0 & 1 \\
\hline
\end{tabular}


Table 9 Descriptive statistics (Continued)

\begin{tabular}{lllll}
\hline Firm profit per worker (mean)(unit:10,000yuan) & 2835 & 3.980 & -20 & 100 \\
Industry sectors & & & & \\
Apparel and textile products manufacturing & 2835 & 0.058 & 0 & 1 \\
Communications equipment, computer manufacturing & 2835 & 0.066 & 0 & 1 \\
Other manufacturing & 2835 & 0.403 & 0 & 1 \\
Electricity, gas and water production & 2835 & 0.042 & 0 & 1 \\
Construction & 2835 & 0.129 & 0 & 1 \\
Transportation, storage and post & 2835 & 0.053 & 0 & 1 \\
Wholesale and retail trade(commerce) & 2835 & 0.217 & 0 & 1 \\
Financial service & 2835 & 0.033 & 0 & 1 \\
Region(County level)variables & & & & \\
Monthly minimum wage & 249 & 655 & 450 & 1000 \\
Yearly lowest living cost & 249 & 3147 & 1680 & 4980 \\
County level average wage & 249 & 25181 & 3842 & 93009 \\
County level GDP per capita & 249 & 44380 & 6526 & 255346 \\
\hline
\end{tabular}

Table 10 Comparing summary statistics from our sample with the 2008 National Economic census

\begin{tabular}{|c|c|c|c|}
\hline \multirow[b]{2}{*}{ Variables } & \multicolumn{2}{|c|}{ Sample } & \multirow{2}{*}{$\begin{array}{l}\text { Census } \\
\text { Mean }\end{array}$} \\
\hline & Mean & Standard error & \\
\hline \multicolumn{4}{|l|}{ Worker level variables } \\
\hline \multicolumn{4}{|l|}{ Gender } \\
\hline Proportion female & 0.395 & 0.489 & 0.376 \\
\hline \multicolumn{4}{|c|}{ Educational attainment (proportion or workers at each level) } \\
\hline College or above & 0.109 & 0.312 & 0.124 \\
\hline Junior college & 0.164 & 0.371 & 0.165 \\
\hline High school & 0.42 & 0.494 & 0.334 \\
\hline Junior high school or below & 0.306 & 0.461 & 0.377 \\
\hline \multicolumn{4}{|l|}{ Industry sectors } \\
\hline Manufacturing & 0.659 & 0.474 & 0.630 \\
\hline Electricity, gas and water production & 0.051 & 0.220 & 0.015 \\
\hline Construction & 0.085 & 0.279 & 0.181 \\
\hline Transportation, storage and post & 0.073 & 0.260 & 0.050 \\
\hline Wholesale and retail trade(commerce) & 0.106 & 0.307 & 0.101 \\
\hline Financial service & 0.026 & 0.160 & 0.023 \\
\hline \multicolumn{4}{|l|}{ Firm level variables } \\
\hline \multicolumn{4}{|l|}{ Firm ownership (proportion of firms) } \\
\hline State funded firm & 0.095 & 0.293 & 0.029 \\
\hline Non-state domestic funded firm & 0.708 & 0.455 & 0.922 \\
\hline Hong Kong, Taiwan, Macao funded firm & 0.075 & 0.263 & 0.025 \\
\hline Foreign funded firm & 0.122 & 0.327 & 0.024 \\
\hline
\end{tabular}


significantly correlated with higher hours worked for workers in the least labor intensive firms and for college graduates.

\section{Competing interests}

The IZA Journal of Labor \& Development is committed to the IZA Guiding Principles of Research Integrity. The authors declare that they have observed these principles.

\section{Authors' information}

Dr. L. Y. is an Associate Professor of Economics at the Nanjing University of Finance and Economics; Dr. T. G. is an IZA Research Fellow and a Professor of Economics and Public Policy at the University of Maryland Baltimore County; S. L. is an IZA Fellow, The Yangtze Scholar Distinguished Professor of Economics at Beijing Normal University and Executive Dean of the China Institute for Income Distribution at Beijing Normal University.

\section{Acknowledgements}

We are grateful for comments from the editor, an anonymous referee, Uma Rani, Tony Fang, Carl Lin and participants at the Conference on Reforming Minimum Wage and Labor Regulation Policy in Developing and Transition Economies (Beijing Normal University, October 18, 2014) and the Chinese Economic Society session on The Effects of Minimum Wage Policy at the ASSA meetings (Boston, January 4, 2015).

Responsible editor: David Lam

\section{Author details}

${ }^{1}$ Department of Economics, Nanjing University of Finance and Economics, No. 3 Wenyuan Road, Yadong New Area, Nanjing, China. ${ }^{2}$ IZA, Bonn, Germany. ${ }^{3}$ Department of Economics, UMBC, 1000 Hilltop Circle, Baltimore, MD, USA. ${ }^{4}$ School of Economics and Business Administration, Rear Main Building 1618, Beijing Normal University, Outer St. 19, Xin Jiekou, Beijing, China.

Received: 1 February 2015 Accepted: 17 August 2015

Published online: 13 October 2015

\section{References}

Alaniz E, Gindling TH, Terrell K (2011) The impact of minimum wages on wages, work and poverty in Nicaragua. Labour Econ 18(S1):S45-S59

Belser P, Rani U (2010) Extending the coverage of minimum wages in India: simulations from household data. ILO working papers, International Labour Organization. http://www.ilo.org/public/libdoc/ilo/2010/110B09_144_engl.pdf. Accessed April 2014

Bhorat H, Kanbur R, Mayet N (2010) Minimum wage violations in South Africa. http://www.kanbur.dyson.cornell.edu/ papers/MinimumWageViolationInSouthAfrica.pdf. Accessed April 2014

Cunningham W (2007) Minimum wages and social policy: Lessons from Developing Countries. World Bank, Washington

Ding SH (2010) Employment effects of minimum wage regulation and cross effect of the employment contracts law. Social Sciences in China XXXI(3)., pp 146-167

Du J, Choi JN (2010) Pay for performance in emerging markets: Insights from China.". J Int Bus Stud 41:671-689

Du Y, Wang M (2008) The implementation of minimum wage system and its effect in China. Journal of Graduate School of Chinese Academy of Social Sciences 6:56-62 (in Chinese)

Durham CC, Bartol KM (2003) Pay for performance. "The Blackwell handbook of principles of organizational behaviour". Locke, Edwin A. Blackwell Publishing, 2003. Blackwell Reference Online. 20 http://www.blackwellreference.com/ subscriber/tocnode.html?id=g9780631215066_chunk_g978063121506612. Accessed July 2015

Fang T, Lin C (2013) Minimum wages and employment in China. IZA Discussion Paper No. 7813, December

Gindling TH, Trejos JD (2010) Improving compliance with legal minimum wages in Costa Rica. UMBC Department of Economics Working Paper. http://www.umbc.edu/economics/wpapers/wp_10_127.pdf. Accessed April, 2014

Han Z, Wei Z (2005) Minimum wage research based on the grey model. Math Practice Theory 35(9):99-104 (in Chinese)

Harrison A, Scorse J (2003) The impact of globalization on compliance with labor standards: a plant-level study. http:// www.people.fas.harvard.edu/ hiscox/HarrisonScorse.pdf. Accessed April 2014

Jia P (2014). Employment and Working Hour Effects of Minimum Wage Increase: Evidence from China. China \& World Economy 22(2):61-80

Kanbur R, Ronconi L, Wedenoja L (2013) Labour law violations in Chile. Int Labour Rev 152(3-4):431-444

Lemos S (2006) Minimum wage effects in a developing country. mimeo, University of Leicester, Leicester

$\mathrm{Li} \mathrm{L}$ (2007) It is hard to implement minimum wages. Management 253:58-59 (in Chinese)

Li X, He P (2010) Effects of the minimum wage on the employment of rural migrant workers-a case study of the Yangtze River Delta. Jiangsu Social Science 4:59-66 (in Chinese)

Ma S, Zhang J, Zhu X (2012) The effect of minimum wage on average wage and employment. Econ Res J 5:132-146 (in Chinese)

Ni J, Wang G, Yao X. (2008) The impact of minimum wages on employment: evidence from China. Paper presented at the Chinese Economist Society Annual Conference, Washington, February 2008

Rani U, Belser P, Oelz M, Ranjbar S (2013) Minimum wage coverage and compliance in developing countries. Int Labour Rev 152(3-4):381-410

Rawski T (2006) Recent developments in China's labour economy. In: Nakagane K, Kojima T (eds) Restructuring China. Toyo Bunko, Tokyo, pp 18-47

Su H, Liu J (2006) The change of minimum wage standard. China Reform 1:54-57 (in Chinese)

Sun C, Tian GQ, Zhang T (2013) Minimum wage and firms' exports in China. Econ Res J 2:42-53 (in Chinese)

Sun ZW, Shu BBS (2011) The standard of the minimum wage, and the wages of peasant-workers: A case study based on Zhujiang Delta. Management World 8:45-56 (in Chinese) 
Wang J, Gunderson M (2011) Minimum wage impacts from a pre-specified research design: China 2000-2007. Contemp Econ Policy 29(3):392-406

Wang J, Gunderson M (2012) Minimum wage effects on employment and wages: dif-in-dif estimates from eastern China. Int J Manpow 33(8):860-876

Wang XL (2012) 'Eleventh Five' minimum wage growth analysis and policy recommendations. China Labor 3:14-16 (in Chinese)

Warner M (1996) Human resources in the people's republic of China: The 'Three Systems' reforms. Hum Resour Manag J 6(2):32-43

Weil D (2005) Public enforcement/private monitoring: Evaluating a new approach to regulating the minimum wage. Ind Labor Relat Rev 58:238-257

Xie Y (2010) The implementation of minimum wage regulation in migrant workers and its determinants: evidence from Jiangsu province. Econ Manage 3:164-170 (in Chinese)

Yang J, Gunderson M, Shi L (2014) The impact of minimum wages on migrant workers' wages. China Institute for Income Distribution Working Paper No. 15. http:/www.ciidbnu.org/news/201402/20140212192553706.html. Accessed August 24, 2014

Submit your manuscript to a SpringerOpen ${ }^{\circ}$ journal and benefit from:

$\checkmark$ Convenient online submission

- Rigorous peer review

- Immediate publication on acceptance

- Open access: articles freely available online

- High visibility within the field

Retaining the copyright to your article

Submit your next manuscript at $\boldsymbol{\sim}$ springeropen.com 